Check for updates

Cite this: RSC Adv., 2019, 9, 20450

Received 6th May 2019

Accepted 22nd June 2019

DOI: $10.1039 / \mathrm{c} 9 \mathrm{ra03380g}$

rsc.li/rsc-advances

\section{Synthesis, computational studies, antimycobacterial and antibacterial properties of pyrazinoic acid-isoniazid hybrid conjugates $\dagger$}

\author{
Siva S. Panda, (D) *a Adel S. Girgis, (D) *b Bibhuti B. Mishra, ${ }^{\text {c }}$ Mohamed Elagawany, ${ }^{\text {ad }}$

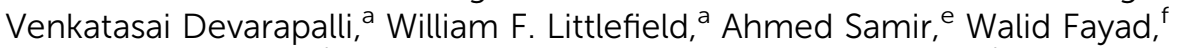 \\ Nehmedo G. Fawzy, ${ }^{b}$ Aladdin M. Srour ${ }^{g}$ and Riham M. Bokhtia ${ }^{\text {ah }}$
}

\begin{abstract}
Benzotriazole and microwave mediated syntheses led to a new set of hybrid conjugates of pyrazinoic acid with isoniazid via amino acid linkers in excellent yields with retention of chirality. Microbiological screening of the synthesized conjugates revealed an exceptionally high activity against some of the pathogenic bacterial strains at low concentrations. Promising antimycobacterial properties were observed against tuberculous and non-tuberculous mycobacteria. Robust molecular models (2D-QSAR and 3Dpharmacophore) support the observed biological properties. Safety profile of the synthesized conjugates against human normal cell (RPE1) was evaluated by MTT technique.
\end{abstract}

\section{Introduction}

Infectious diseases continue to pose a major threat to human health caused by pathogenic microorganisms, such as viruses, bacteria, fungi or parasites. According to the World Health Organization (WHO), despite all the progress made to control or cure infectious diseases, the major challenges persist in the new drug development with high efficacy/selectivity for these diseases. TB (tuberculosis) is one of the top 10 causes of death worldwide and the leading cause of mortality/morbidity from a single infectious agent (above HIV/AIDS). Millions of people continue to fall sick with TB each year. In 2017, TB caused an estimated 1.3 million deaths (range, 1.2-1.4 million) among HIVnegative people and there were an additional 300000 deaths from TB (range, 266 000-335 000) among HIV-positive people.

${ }^{a}$ Department of Chemistry \& Physics, Augusta University, Augusta, GA 30912, USA. E-mail: sspanda12@gmail.com

${ }^{b}$ Department of Pesticide Chemistry, National Research Centre, Dokki, Giza 12622, Egypt. E-mail: girgisas10@yahoo.com

${ }^{c}$ Department of Immunology and Microbial Disease, Albany Medical College, $47 \mathrm{New}$ Scotland Avenue, Albany, NY-12208, USA

${ }^{d}$ Department of Pharmaceutical Chemistry, Faculty of Pharmacy, Damanhour University, Damanhour, Egypt

${ }^{e}$ Microbiology Department, Faculty of Veterinary Medicine, Cairo University, Cairo, Egypt

${ }^{f}$ Drug Bioassay-Cell Culture Laboratory, Pharmacognosy Department, National Research Centre, Dokki, Giza, 12622, Egypt

${ }^{g}$ Department of Therapeutic Chemistry, National Research Centre, Dokki, Giza 12622, Egypt

${ }^{h}$ Department of Pharmaceutical Organic Chemistry, Faculty of Pharmacy, Zagazig University, Zagazig, 44519, Egypt

$\dagger$ Electronic supplementary information (ESI) available. See DOI: 10.1039/c9ra03380g
Nearly 10.0 million people (range, 9.0-11.1 million) developed TB disease in 2017: among which 5.8 million were men, 3.2 million women and 1.0 million were children (WHO, 2018). ${ }^{1}$

TB disease is caused by a bacterial pathogen Mycobacterium tuberculosis, that existed for millennia and continues to be the leading cause of infectious disease deaths globally. ${ }^{2}$ It is known to cause pulmonary infection and become extremely pervasive within the lungs and between subjects. The current directly observed treatment, short course (DOTS) tuberculosis therapy requires a minimum of six months of treatment consisting of two months of the intensive phase of treatment with the firstline drugs including isoniazid (INH), rifampin (RIF), pyrazinamide (PZA) and ethambutol (EMB), followed by another four months of therapy with INH and RIF alone. Among the first line antibiotics, PZA is a highly effective bactericidal drug which is known to penetrate into TB lesions and remain active in the highly acidic environment of the TB granuloma. The parent prodrug is metabolized via pyrazinamidase (PZase) to pyrazinoic acid; which is the active form of the drug. However, the exact mechanism of action is not clear. Like PZA, INH is also a prodrug that requires the activity of mycobacterial catalase KatG. This interaction activates a series of reactions that eventually lead to the inhibition of mycolic acid synthesis, building block of mycobacterial cell wall. Inappropriate treatment, poor drug quality, and inadequate drug intake or treatment, all contribute to the emergence of drug resistant bacterial strains classified as multidrug-resistant (MDR) and extremely drug resistant (XDR) strains. ${ }^{3}$ Currently, existing drugs are of limited efficacy against drug resistance TB strains besides their known side effects. ${ }^{4}$

Mycobacterium bovis is another Mycobacterium strain that causes TB disease in animals and humans. In addition to 
Mycobacterium tuberculosis and Mycobacterium bovis, there are many non-tuberculous mycobacteria like Mycobacterium marinum and Mycobacterium fortuitum also cause various infections in humans. Although many therapeutic agents were developed for non-tuberculous mycobacterial infections, no standard treatment protocol was approved due to their natural multidrug resistance. ${ }^{5}$

Drug resistance is a major global health concern for a plethora of bacterial and fungal infections. ${ }^{6}$ Gram-positive and Gram-negative bacterial strains are involved in the majority of infectious diseases. ${ }^{7,8}$ The rapid emergence of MDR infections necessitates the design and synthesis of novel antimicrobial molecules. The development of novel antimicrobial drugs is key to the treatment of infectious diseases, especially for which combinatorial drug treatments are needed.

Sub-optimal therapy caused by inefficient cellular penetration is a major issue associated with drug resistance. Many therapeutic agents owing to their charge, hydrophilic property, and/or size and stability under physiological conditions are not suitable for treating intracellular bacterial infections that require the drug to penetrate the cell membrane of the host and also the pathogen. To compensate for the reduced penetration and bioavailability, high drug doses are often used that causes strong adverse effects for vital organs. Synthetic vectors can offer a solution for these problems associated with drug delivery, overcoming the limitations such as bioavailability and/ or cytotoxicity. Among such synthetic vectors, cell-penetrating peptides and amino acids have been successfully utilized because of their drug carrier ability across cell membranes. ${ }^{9}$ Recently, several approaches have been reported to combat the MDR problem. ${ }^{\mathbf{1 0 - 1 3}}$

The present study deals with the synthesis of novel pyrazinoic acid-isoniazid conjugates connected through an amino acid linker using molecular hybridization approach and investigating their properties against a variety of microbial strains including, aerobic bacteria, tuberculous and non-tuberculous mycobacteria. Conjugation of effective drug fragments for developing novel agents is a well successful approach in drug design. ${ }^{\mathbf{1 4}}$ Microwave methodology is utilized to synthesize the targeted conjugates since microwave protocol is well known in medicinal chemistry for synthesizing drug like molecules in high yield and purity. ${ }^{15}$ Molecular modeling techniques are effective tools for understanding and validation of the biological data.

\section{Results and discussion}

\section{Chemistry}

Synthesis of the targeted hybrids was initially studied by activating the Boc-protected amino acids (1a-g) with $1 H$-benzotriazole. The boc-protected aminoacyl benzotriazoles (3a-g) were treated with isoniazid (4) in the presence of trimethylamine in acetonitrile at $20{ }^{\circ} \mathrm{C}$ for $2 \mathrm{~h}$. According to the TLC profile, the reaction was completed but the formed compounds $5 \mathbf{a}-\mathbf{g}$ could not be isolated in good yield because of the hydrophilic nature of isoniazid (4) (Scheme 1). Different conditions

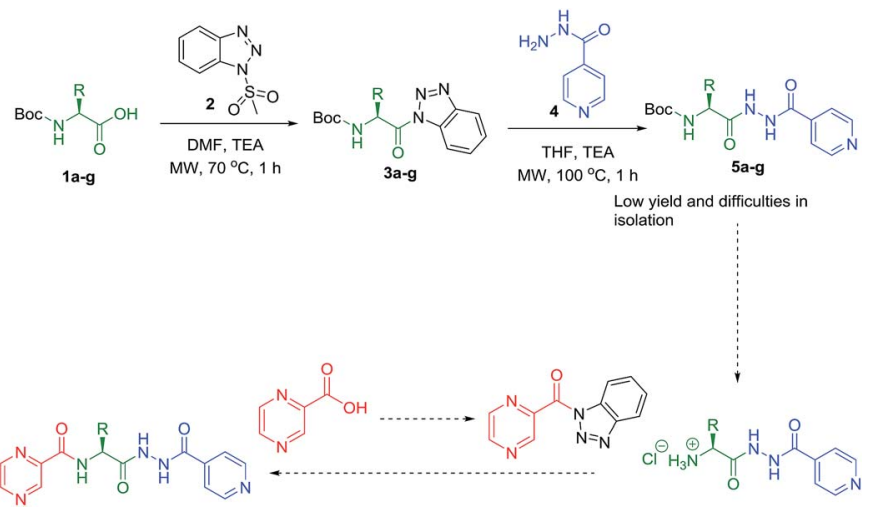

Scheme 1 Synthesis of POA hybrids through reaction of isoniazid and amino acid (Route I).

were utilized but none of them was successful to isolate the conjugates $\mathbf{5 a - g}$ in good yields.

Slight modification was considered for the synthetic strategy, where the pyrazinoic acid (POA, 6) was activated as benzotriazolyl derivative $\mathbf{8}$ obeying the reported procedure ${ }^{\mathbf{1 6}}$ and coupled with free amino acids $(\mathbf{9 a}-\mathbf{g})$ in a mixture of acetonitrile and water $(7: 3)$ at $20{ }^{\circ} \mathrm{C}$ for $2 \mathrm{~h}$ in the presence of 1.5 equivalents of trimethylamine to give compounds $10 a-g$. In our previous communication, ${ }^{\mathbf{1 4}}$ we reported that we failed to prepare benzotriazole derivatives of POA-amino acid conjugates 10a-g. This time we were able to optimize the reaction condition and prepare the POA-aminoacyl benzotriazoles (11a$\mathbf{g}$ ) in pure form by treating $\mathbf{1 0 a}-\mathbf{g}$ with benzotriazole (7) in presence of thionyl chloride at $-15{ }^{\circ} \mathrm{C}$ for $5-6 \mathrm{~h}$. Compounds 11a-g were irradiated under microwave condition with 4 in the presence of trimethylamine at $100{ }^{\circ} \mathrm{C}$ for $1 \mathrm{~h}$ to obtain our desired conjugates 12a-g in good yields without losing the chiral integrity (Scheme 2). The confirmation of chiral integrity was established by HPLC studies by comparing the spectra of $\mathrm{L}^{-}$ phenylalanine and DL-phenylalanine containing conjugates.

To better understand the role and effect of amino acids in biological properties, we have also synthesized hybrid of pyrazinoic acid and isoniazid $\mathbf{1 3}$ without any linker (Scheme 3). As
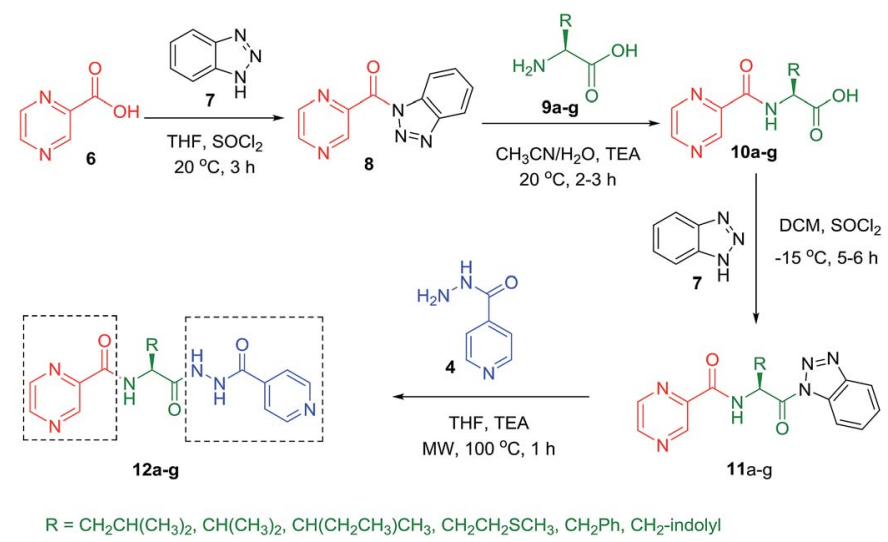

Scheme 2 Synthesis of POA hybrids through reaction of POA-aminoacyl benzotriazoles with isoniazid (Route II). 


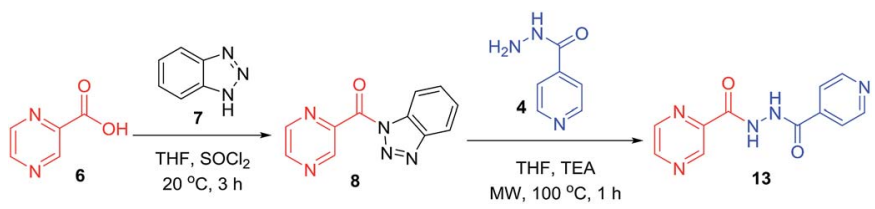

Scheme 3 Synthesis of POA-INH hybrid.

isoniazid is the pro-drug of isonicotinic acid, we prepared the bis conjugate of isonicotinic acid to compare the biological property of the hybrid 13 and bis conjugate 16 of isoniazid (Scheme 4). Conjugates 13 and 16 were previous reported and synthesized by using various catalysts and reagents. ${ }^{\mathbf{1 7 - 2 0}}$ However, we were able to complete the synthesis by utilizing the aforementioned benzotriazole methodology under microwave irradiation in good yield and purity.

\section{Biological studies}

Aerobic antibacterial properties. Antibacterial properties were investigated for the synthesized compounds along with parent drugs pyrazinamide (PZA), isoniazid (INH) and a standard drug ciprofloxacin against a variety of Gram-positive (Staphylococcus aureus, Enterococcus faecalis) and Gramnegative (Klebsiella pneumonia, Proteus vulgaris, Pseudomonas aeruginosa) clinical isolate bacteria utilizing the standard technique. ${ }^{21}$ From the results obtained (Table 1) the following observations can be stated.

All the tested conjugates $(\mathbf{1 0 a}-\mathbf{g}$ and $\mathbf{1 2 a}-\mathbf{g})$ show high antibacterial properties at sub-micromolar values $(\mathrm{MIC}=0.44-0.07$ $\mu \mathrm{M})$ with potency higher than that of the standard reference used (MIC of ciprofloxacin $=1.21 \mu \mathrm{M}$ ) against Enterococcus faecalis. Similar observations were also shown for most of the tested conjugates against Proteus vulgaris (except compounds 10a and 12f) and Pseudomonas aeruginosa (except compounds 10b, 10f, and 12a) with $\mathrm{MIC}$ values $=0.14-0.27,0.13-0.51 \mu \mathrm{M}$, respectively relative to the standard reference ciprofloxacin $(\mathrm{MIC}=6.04,12.07$ $\mu \mathrm{M}$, respectively). It has also been noticed that all the synthesized conjugates 12a-g show higher potency than their precursors 10a-g against Klebsiella pneumonia. Similar inhibition properties were noticed towards Enterococcus faecalis [compounds $\mathbf{1 2 b}$ is an exception revealing antimicrobial properties close to its precursor 10b $(\mathrm{MIC}=0.33,0.13 \mu \mathrm{M}$, respectively)].

Establishing SAR (structure-activity relationships) with this information is difficult. However, we noticed some evidence like utilization of tryptophan enhances the antimicrobial properties against all the tested microorganisms than phenylalanine as

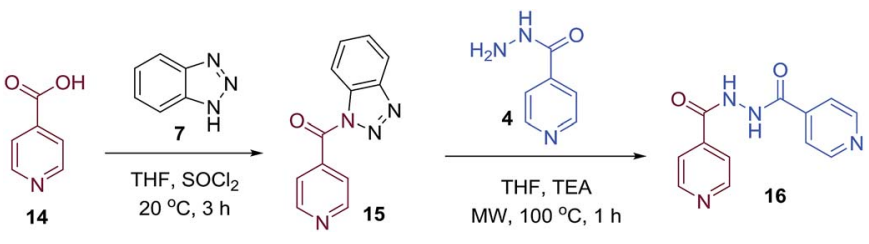

Scheme 4 Synthesis of INH bis-conjugate. observed for the synthesized compounds $10 \mathrm{~g} / \mathbf{1 2 g}$ versus $10 \mathrm{e} /$ 12e. This can be attributed to the effect of indolyl heterocycle as indole analogues are well known for potential activities. The synthesized bis-conjugate 16 seems higher antimicrobial agent against $S$. aureus, $K$. pneumonia, and $P$. vulgaris than the hybrid analog $13(\mathrm{MIC}=16.51,16.51,0.12 ; 32.89,32.89,263.13 \mu \mathrm{M}$, respectively). It also reveals close property to that of $\mathbf{1 3}$ against E. faecalis (MIC $=65.78,66.05 \mu \mathrm{M}$ for compounds 13 and 16, respectively). Overall hybrid conjugates with amino acids are more active than the hybrid conjugates without amino acid as a linker. In our future studies, it is intended to explore more possible linkers as well as use dipeptides and tripeptides to establish an evidence-based SAR and to develop more potent antibacterial agents.

Antimycobacterial properties. Antimycobacterial properties of the synthesized compounds 10a-g, 12a-g, 13 and 16 were screened against clinical isolate tuberculous (Mycobacterium bovis) and non-tuberculous (Mycobacterium marinum, Mycobacterium fortuitum) strains using the standard technique. ${ }^{\mathbf{1 6 , 2 2}}$ Antituberculosis properties of the conjugates were also studied against highly virulent Mycobacterium tuberculosis at Albany Medical College, Albany, NY. All the experimental data were compared with the reference standards PZA, INH. Based on the mycobacterial observations (Table 2, Fig. 1 and 2), the following SAR are observed.

Mycobacterium marinum. Some of the synthesized conjugates reveal high anti-mycobacterial properties against $M$. marinum (about three folds potency; MIC $=26.7,25.6 \mu \mathrm{M}$ of $\mathbf{1 2 d}$ and 12f, respectively) than the standard references used ( $\mathrm{MIC}=81.2$, $72.9 \mu \mathrm{M}$ of PZA, INH, respectively). Other conjugates synthesized show potency comparable (slight enhancement) to that of the standard references $(\mathrm{MIC}=46.6-58.4 \mu \mathrm{M}$ for conjugates 12a-c, 12e and 12g). Compounds 10a and 10f show biological properties ( $\mathrm{MIC}=84.3,73.7 \mu \mathrm{M}$, respectively) close to that of the standard references used. The synthesized conjugates 12a-g are more potent than their corresponding intermediates 10a-g. The hybrid $13(\mathrm{MIC}=41.1 \mu \mathrm{M})$ seems an effective agent than its precursors (PZA and NIH) and the bis-conjugate 16 ( $\mathrm{MIC}=82.6$ $\mu \mathrm{M})$. The data clearly indicates the role of amino acids in the hybrid conjugates and probably synergetic effect of the two parent molecules. Interestingly, the aromatic amino acid residues show enhanced activity than the others.

Mycobacterium fortuitum. Compound 12f seems superior among all the synthesized analogs $(\mathrm{MIC}=25.6 \mu \mathrm{M})$ with a potency about 5.6, 3.2 folds than that of the standard references used ( $\mathrm{MIC}=145.8,81.2 \mu \mathrm{M}$ of INH, PZA, respectively). Many of the synthesized compounds ( $\mathrm{MIC}=46.6-58.4 \mu \mathrm{M}$ of conjugates 12a-e and 12g) also reveal promising biological properties relative to the standards. All the synthesized conjugates $12 \mathbf{a}-\mathbf{g}$ are of high potency than their corresponding intermediates 10a-g. Hybrid conjugate 13 is of higher potency than the bis-conjugate 16. Again we observed tryptophan plays some important role in enhancing the activity.

Mycobacterium bovis. Only compounds 13 and 16 (MIC = $82.2,82.6 \mu \mathrm{M}$, respectively) show promising antimycobacterial properties (about 1.8-2.0 folds) than the standard references (MIC $=145.8,162.4 \mu \mathrm{M}$ of INH, PZA, respectively). The results 
Table 1 Antimicrobial properties of the tested compounds against aerobic bacteria

Minimum inhibitory concentration (MIC), $\mu \mathrm{g} \mathrm{mL} \mathrm{L}^{-1}(\mu \mathrm{M})$

\section{Staphylococcus} aureus Enterococcus faecalis

Klebsiella pneumoniae

Proteus vulgaris

Pseudomonas aeruginosa

1<smiles>NC(=O)c1cnccn1</smiles>

$1024(8317.43) \quad 0.12(0.97)$

$64(519.84)$

$8(58.33)$

$64(466.67) \quad 16(116.67)$

$0.4(1.21)$

$0.4(1.21)$

$2(6.04)$

$2(6.04)$

$4(12.07)$

Ciprofloxacin<smiles>CC(C)CC(NC(=O)c1cnccn1)C(=O)O</smiles>

$1024(4315.96) \quad 0.03(0.13)$<smiles>CC(C)C(NC(=O)c1cnccn1)C(=O)O</smiles>

$512(2293.58) \quad 0.03(0.13)$

$16(67.44) \quad 0.03(0.13)$

8 (33.72)

$0.06(0.25)$

$0.12(0.51)$

6<smiles>CC[C@H](C)[C@H](NC(=O)c1cnccn1)C(=O)O</smiles><smiles>CSCCC(NC(=O)c1cnccn1)C(=O)O</smiles>

$16(62.67)$

$0.03(0.12)$

$64(250.69)$

$0.06(0.24)$

$0.12(0.47)$

10d

8<smiles>O=C(NC(Cc1ccccc1)C(=O)O)c1cnccn1</smiles>

$64(235.92) \quad 0.12(0.44)$

$64(235.92)$

$0.06(0.22)$

$0.12(0.44)$

9<smiles>O=C(NC(Cc1ccccc1)C(=O)O)c1cnccn1</smiles>

16 (58.98)

$0.06(0.22)$

16 (58.98) 
Table 1 (Contd.)

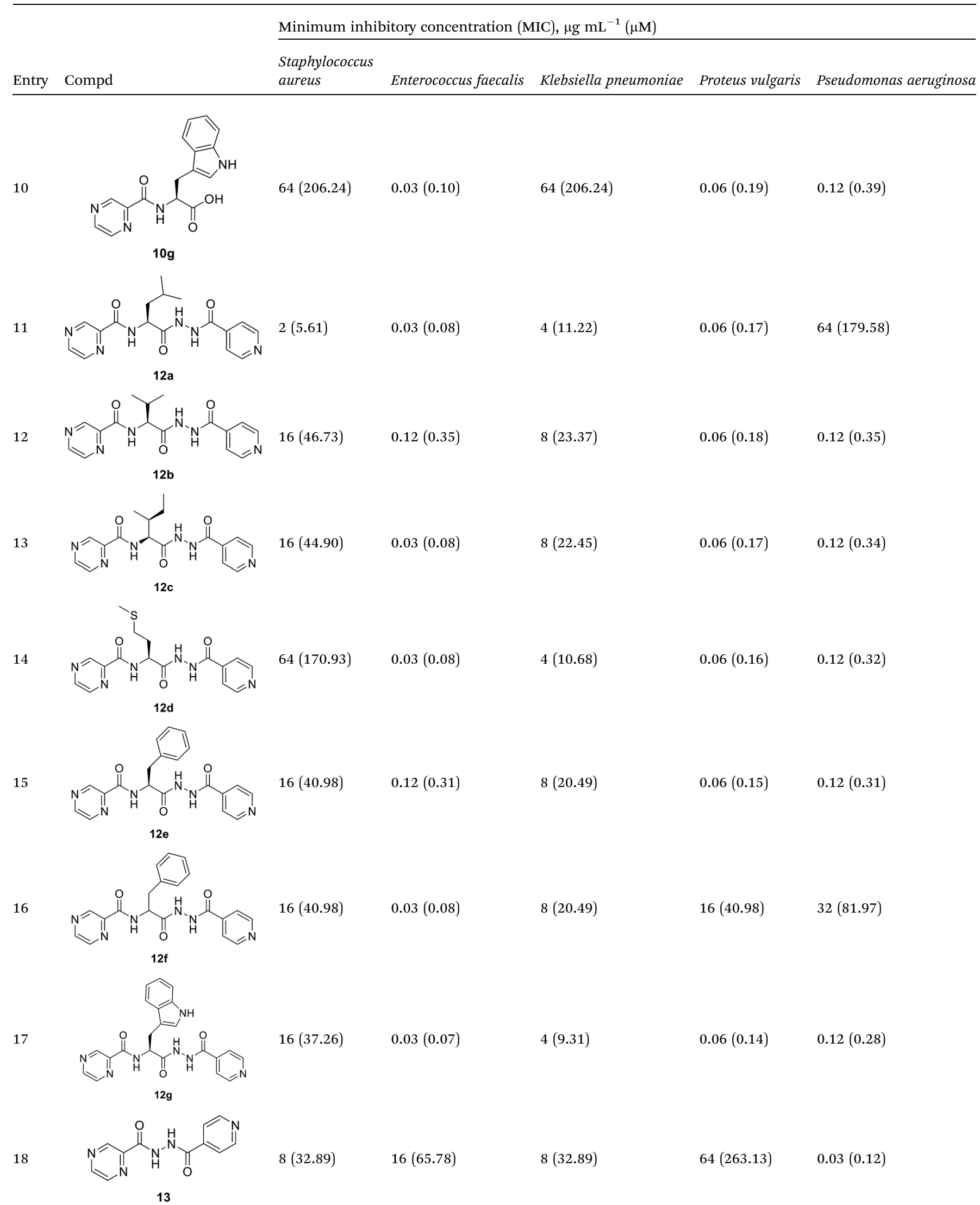

13 
Minimum inhibitory concentration (MIC), $\mu \mathrm{g} \mathrm{mL}^{-1}(\mu \mathrm{M})$

Staphylococcus

Entry Compd aureus

Enterococcus faecalis Klebsiella pneumoniae Proteus vulgaris Pseudomonas aeruginosa

19<smiles>O=C(NNC(=O)c1ccncc1)c1ccncc1</smiles>

$4(16.51) \quad 16(66.05)$

$4(16.51)$

$0.03(0.12)$

$0.06(0.25)$

16

indicate the hybrid conjugates with amino acid linker lost the activity.

Mycobacterium tuberculosis. The PZA activity was not observed at $30 \mu \mathrm{g} \mathrm{mL}{ }^{-1}$ concentration at $\mathrm{pH}=7.0$. However, at this concentration, significant growth inhibition was observed for the synthesized conjugates even though the parent PZA is known to exhibit $M$. tuberculosis activity in vitro at acidic $\mathrm{pH}<$ 6.0. INH showed $>70 \%$ growth inhibition at $30 \mu \mathrm{g} \mathrm{mL}^{-1}$ concentration, while compound $\mathbf{1 3}$ hybrid compounds exhibit same growth inhibition at concentration as low as $3 \mu \mathrm{g} \mathrm{mL}$. Moreover, the hybrid conjugates 12a-g exhibited $>95 \%$ growth inhibitory activity at $30 \mu \mathrm{g} \mathrm{mL} \mathrm{m}^{-1}$ and $>80 \%$ growth inhibition at $10 \mu \mathrm{g} \mathrm{mL}^{-1}$ concentration. Notably, PZA-INH hybrid compounds exhibit potent bactericidal effect at physiological PH, 7.0 (Fig. 1 and 2). We clearly notice the effect of hybrid conjugates over the corresponding intermediates 10a-g. We believe the combination along with amino acid enhance the activity of the parent drugs.

Antiproliferative properties. Antiproliferative properties of the synthesized compounds were screened against RPE1 (normal human immortalized retinal epithelial) cell line to determine the toxicity/selectivity towards normal cell by the standard MTT technique. ${ }^{23}$ The proliferation properties of RPE1

Table 2 Anti-mycobacterial properties of the tested compounds

\begin{tabular}{lllll}
\hline & \multicolumn{4}{c}{$\begin{array}{l}\text { Minimum inhibitory concentration }(\mathrm{MIC}), \mu \mathrm{g} \\
\mathrm{ml}^{-1}(\mu \mathrm{M})\end{array}$} \\
\cline { 3 - 5 } Entry & Compd & M. marinum & M. fortuitum & M. bovis \\
\hline 1 & PZA & $10(81.2)$ & $10(81.2)$ & $20(162.4)$ \\
2 & INH & $10(72.9)$ & $20(145.8)$ & $20(145.8)$ \\
3 & $\mathbf{1 0 a}$ & $20(84.3)$ & $20(84.3)$ & $>20(>84.3)$ \\
4 & $\mathbf{1 0 b}$ & $>20(>89.6)$ & $>20(>89.6)$ & $>20(>89.6)$ \\
5 & $\mathbf{1 0 c}$ & $>20(>84.3)$ & $>20(>84.3)$ & $>20(>84.3)$ \\
6 & $\mathbf{1 0 d}$ & $>20(>78.3)$ & $>20(>78.3)$ & $>20(>78.3)$ \\
7 & $\mathbf{1 0 e}$ & $>20(>73.7)$ & $>20(>73.7)$ & $>20(>73.7)$ \\
8 & $\mathbf{1 0 f}$ & $20(73.7)$ & $>20(>73.7)$ & $>20(>73.7)$ \\
8 & $\mathbf{1 0 g}$ & $>20(>64.5)$ & $>20(>64.5)$ & $>20(>64.5)$ \\
10 & $\mathbf{1 2 a}$ & $20(56.1)$ & $20(56.1)$ & $>20(>56.1)$ \\
11 & $\mathbf{1 2 b}$ & $20(58.4)$ & $20(58.4)$ & $>20(>58.4)$ \\
12 & $\mathbf{1 2 c}$ & $20(56.1)$ & $20(56.1)$ & $>20(>56.1)$ \\
13 & $\mathbf{1 2 d}$ & $10(26.7)$ & $20(53.4)$ & $>20(>53.4)$ \\
14 & $\mathbf{1 2 e}$ & $20(51.2)$ & $20(51.2)$ & $>20(>51.2)$ \\
15 & $\mathbf{1 2 f}$ & $10(25.6)$ & $10(25.6)$ & $>20(>51.2)$ \\
16 & $\mathbf{1 2 g}$ & $20(46.6)$ & $20(46.6)$ & $>20(>46.6)$ \\
17 & $\mathbf{1 3}$ & $10(41.1)$ & $10(41.1)$ & $20(82.2)$ \\
18 & $\mathbf{1 6}$ & $20(82.6)$ & $20(82.6)$ & $20(82.6)$
\end{tabular}

cell lines are $96.4-80.1 \%$ at $100 \mu \mathrm{M}$ suggest that the synthesized conjugates are likely to be safe to the human normal cell (ESI Table S1†).

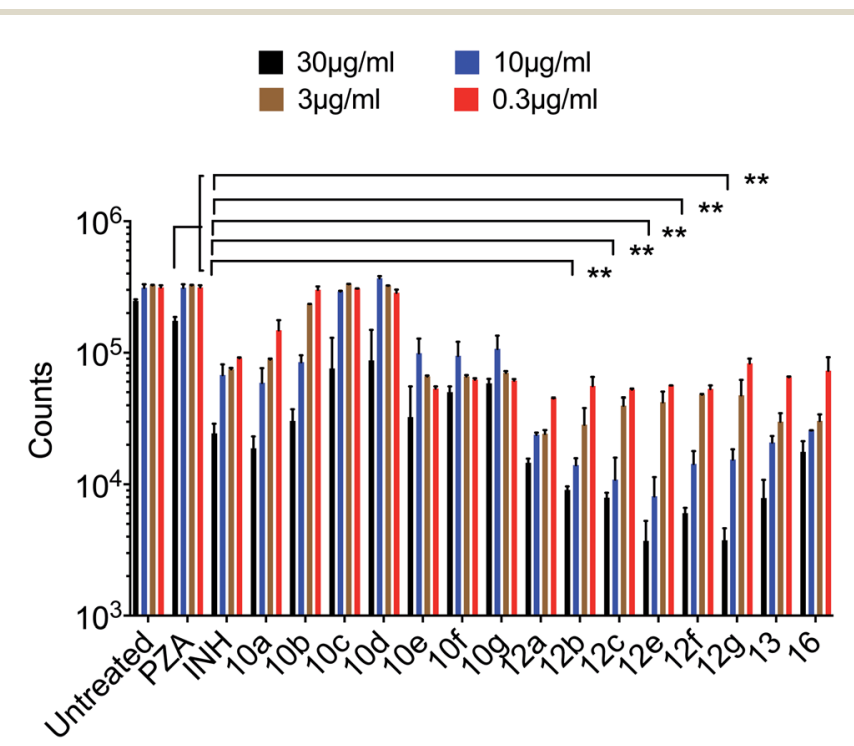

Fig. 1 Bacterial growth was measured by recording luciferase counts in an IVIS-spectrum imaging system (data are presented as mean \pm $\mathrm{SD})$, one-way ANOVA Tukey's multiple comparison test. **, $p<0.001$.

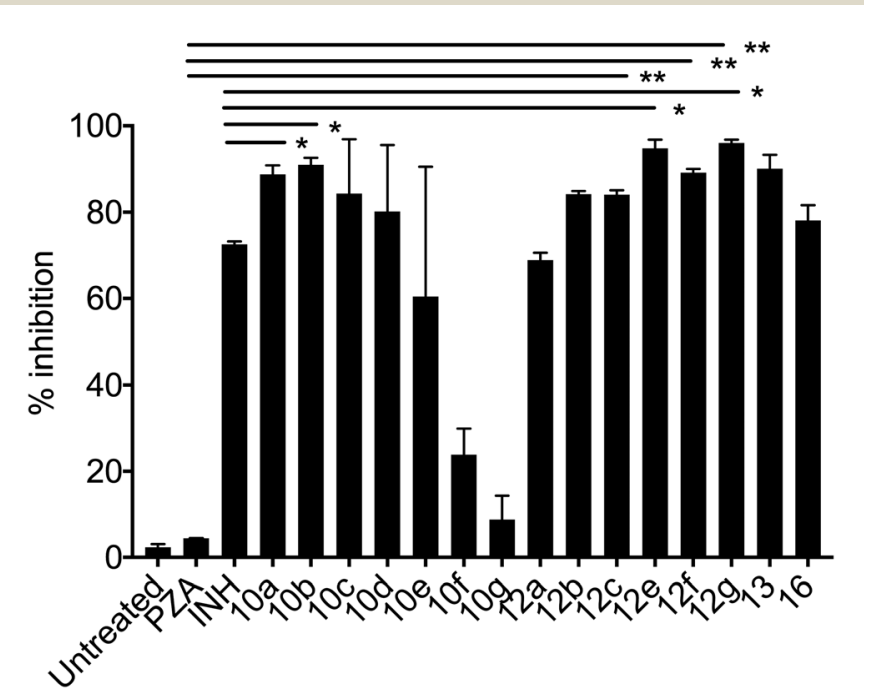

Fig. $2 \%$ growth inhibition was shown compared to untreated controls (data are presented as mean $\pm \mathrm{SD}$ ). Student's two-tailed $t$ test. *, $p<$ $0.05 ; * *, p<0.001$. 


\section{Computational studies}

2D-QSAR. 2D-QSAR (quantitative structure activity relationships) is a successful technique used intensively in medicinal chemistry. It is capable to express the biological properties in terms of mathematical equation(s) of descriptors (physicochemical) parameters. ${ }^{24}$ The biologically active compounds against Mycobacterium marinum, Mycobacterium fortuitum and Mycobacterium tuberculosis were considered for 2D-QSAR studies utilizing CODESSA-Pro software that allows understanding the parameters governing bio-properties and also validates the bio-observations.

Mycobacterium marinum. The two-descriptor model was determined to describe the properties of the biologically active agents against Mycobacterium marinum (ESI Table S2 $\dagger$ ). Maximum e-n attraction for bond $\mathrm{C}-\mathrm{N}$ is a semi-empirical descriptor with level of significance $=-4.762$. This descriptor participates negatively in the 2D-QSAR model. In other words, the highest value of the descriptor the more anti-mycobacterial potency of the compound as observed in the high effective agent synthesized 12d $\left(\mathrm{MIC}_{\text {observed }}=26.7, \mathrm{MIC}_{\text {estimated }}=30.8 \mu \mathrm{M}\right)$ relative to $16\left(\mathrm{MIC}_{\text {observed }}=82.6, \mathrm{MIC}_{\text {estimated }}=82.3 \mu \mathrm{M}\right)$ that possess descriptor values $=330.7008,329.2578$, respectively (ESI Tables S3 and S4†). Nuclear-electron attraction energy between two given atoms is determined by eqn (1). ${ }^{25}$

$$
E_{\mathrm{ne}}(\mathrm{AB})=\sum_{\mathrm{B}} \sum_{\mu, v \in \mathrm{A}} P_{\mu \nu}\left\langle\mu\left|\frac{Z_{\mathrm{B}}}{R_{\mathrm{iB}}}\right| \nu\right\rangle
$$

where A, B are two atomic species. $P_{\mu v}$ is the density matrix elements over atomic basis $\{\mu v\} . Z_{\mathrm{B}}$ is the charge of atomic nucleus $\mathrm{B}, R_{\mathrm{iB}}$ is the distance between the electron and atomic nucleus B. $\left\langle\mu\left|\frac{Z_{\mathrm{B}}}{R_{\mathrm{B} \mathrm{B}}}\right| \nu\right\rangle$ is the electron-nuclear attraction integrals on atomic basis $\{\mu \nu\}$.

Maximum e-e repulsion for bond $\mathrm{C}-\mathrm{C}$ is also a semiempirical descriptor participates negatively in the BMLR-QSAR model. Electron-electron repulsion between two given atoms can be calculated by eqn (2). ${ }^{25}$

$$
E_{\mathrm{ee}}(\mathrm{AB})=\sum_{\mu, v \in \mathrm{A} \lambda, \sigma \in \mathrm{B}} \sum_{\mu \nu} P_{\lambda \sigma}\langle\mu \nu \mid \lambda \sigma\rangle
$$

where A, B are two atomic species. $P_{\mu \nu}, P_{\lambda \sigma}$ are the density matrix elements over atomic basis $\{\mu \nu \lambda \sigma\} .\langle\mu \nu \mid \lambda \sigma\rangle$ is the electron repulsion integrals on atomic basis $\{\mu \nu \lambda \sigma\}$.

Mycobacterium fortuitum. Two semi-empirical descriptor model is observed for the biologically active agents against $M$. fortuitum (ESI Table S5 $\dagger$ ). Both of the descriptors positively participate in the BMLR-QSAR model, i.e. the higher descriptor value the lower biological properties (ESI Tables S6 and S7 $\dagger$ ). Electron-electron repulsion energy for a given atomic species can be calculated by eqn (3). ${ }^{25}$

$$
E_{\mathrm{ee}}(\mathrm{A})=\sum_{\mathrm{B} \neq \mathrm{A} \mu, v \in \mathrm{A} \lambda, \sigma \in \mathrm{B}} \sum_{\mu \nu} P_{\lambda \sigma}\langle\mu \nu \mid \lambda \sigma\rangle
$$

where A, B are two atomic species. $P_{\mu \nu}, P_{\lambda \sigma}$ are the density matrix elements over atomic basis $\{\mu \nu \lambda \sigma\} .\langle\mu \nu \mid \lambda \sigma\rangle$ is the electron repulsion integrals on atomic basis $\{\mu \nu \lambda \sigma\}$.
Mycobacterium tuberculosis. Three-descriptor model was observed for the 2D-QSAR study of the tested compounds against $M$. tuberculosis utilizing the $\log$ value of \% growth inhibition at $30 \mu \mathrm{g} \mathrm{mL}{ }^{-1}$ (ESI Tables S8-S10†). Minimum e-e repulsion for bond $\mathrm{H}-\mathrm{N}$ and maximum e-e repulsion for bond $\mathrm{H}-\mathrm{C}$ (semi-empirical descriptors, $t=9.543,7.207$, respectively) can be determined by the mentioned eqn (2). Maximum coulombic interaction for bond $\mathrm{C}-\mathrm{O}$ is also a semi-empirical descriptor $(t=-14.963)$. Total interaction energy between two given atomic species can be calculated by eqn (4). ${ }^{25}$

$$
E_{\mathrm{tot}}(\mathrm{AB})=E_{\mathrm{C}}(\mathrm{AB})+E_{\mathrm{exc}}(\mathrm{AB})
$$

where, $\mathrm{A}$ and $\mathrm{B}$ are two atomic species. $E_{\mathrm{C}}(\mathrm{AB})$ and $E_{\text {exc }}(\mathrm{AB})$ are electrostatic interaction and exchange energies between the two atomic species, respectively.

Validation of the 2D-QSAR models. Due to the short training set utilized in the 2D-QSAR study, internal validation seems the most appropriate technique. ${ }^{23}$ Goodness of the QSAR models are established by the statistical parameters [including squared correlation coefficient $\left(R^{2}\right)$ and its leave-one-out $\left(R^{2}\right.$ cvOO), $F$ (Fisher criteria) and $s^{2}$ (standard deviation)] $\left(R^{2}=0.908,0.984\right.$, $0.965 ; R^{2}$ cvOO $=0.829,0.962,0.892 ; F=39.543,240.314$, 82.181; and $s^{2}=0.003,0.001,0.004$ for the BMLR-QSAR models of M. marinum, M. fortuitum, and M. tuberculosis, respectively). Estimated properties of the effective agents by the BMLR-QSAR models are comparable to their observed values preserving their potency among each other and to the standard references used (Fig. 3-8; ESI Tables S3, S6 and S9†).

3D-pharmacophore modelling. 3D-pharmacophore modeling is an important computational technique explains the biological/pharmacological properties of compound(s) through alignment of the structural elements with chemical features in 3D-array. ${ }^{26}$ The biologically active compounds were undertaken by Discovery Studio 2.5 software searching for the 3D-pharmacophoric modeling in which alignment of the synthesized conjugates describes the observed biological properties. $^{\mathbf{2 6}}$

Mycobacterium marinum. 3D-pharmacophoric modeling of the biologically active compounds against Mycobacterium marinum reveals 3D-array of three chemical features [two hydrogen bonding acceptors (HBA-1, HBA-2) and one hydrogen bonding donor (HBD)] (ESI Fig. S1 and S2 $\dagger$ ). The estimated/predicted properties of the tested compounds due to alignment in the $3 \mathrm{D}$-pharmacophore are presented in ESI Table S11. $\dagger$ From the observed data it has been noticed that, the N-2 of isonicotinic acid hydrazide is aligned with the pharmacophoric HBD in compounds $\mathbf{1 2 d}$ and $\mathbf{1 2 g}$, which are effective conjugates synthesized against $M$. marinum $\left(\mathrm{MIC}_{\text {observed }}=26.7\right.$, 46.6; $\mathrm{MIC}_{\text {estimated }}=33.4,38.1 \mu \mathrm{M}$ for $12 \mathrm{~d}$ and $12 \mathrm{~g}$, respectively). However, slight displacement is observed for compounds 12a, b and 12e, "which are also promising agents relative to the standard reference used (INH)" where, the N-1 of isonicotinic acid hydrazide of these compounds is aligned with the pharmacophoric HBD $\left(\mathrm{MIC}_{\text {observed }}=56.1,58.4,51.2 ; \mathrm{MIC}_{\text {estimated }}=\right.$ $46.9,43.7,39.3 \mu \mathrm{M}$ for $12 \mathrm{a}, \mathbf{b}$ and $12 \mathrm{e}$, respectively). The 


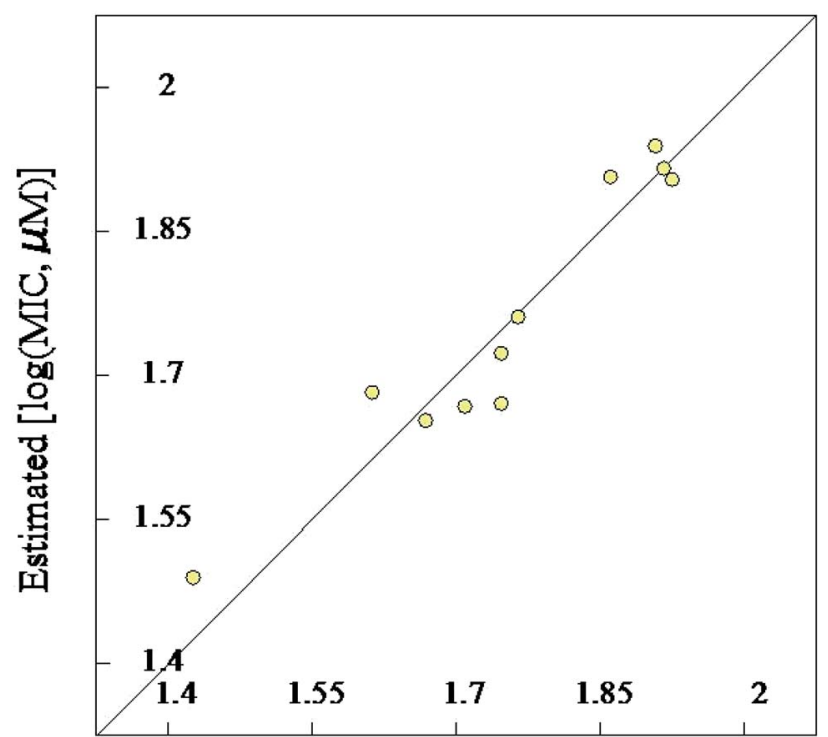

Observed [log(MIC, $\mu \mathrm{M})]$

Fig. 3 BMLR-QSAR model plot of correlations representing the observed vs. predicted $\log (\mathrm{MIC}, \mu \mathrm{M})$ values for the tested compounds against Mycobacterium marinum.

estimated properties of the tested compounds are validated with the experimental observations which help to establish the SAR.

Mycobacterium fortuitum. Three chemical features [two hydrogen bonding donors (HBD-1, HBD-2) and one hydrogen bonding acceptor (HBA)] were exhibited by the 3Dpharmacophore due to the tested bioactive agents against Mycobacterium fortuitum (ESI Fig. S3 and S4 $\dagger$ ). Compound 12g, which is one of the high potent hits synthesized against $M$. fortuitum reveals alignment of isonicotinic acid hydrazide $\mathrm{N}-1$ with HBD-1 $\left(\mathrm{MIC}_{\text {observed }}=46.6, \mathrm{MIC}_{\text {estimated }}=44.7 \mu \mathrm{M}\right)$. However, $\mathrm{N}-1$ and N-2 of the hyrazide moiety of compounds $\mathbf{1 2 d}$ and 12a are aligned with HBD-2 and HBD-1, respectively $\left(\mathrm{MIC}_{\text {observed }}=53.4,56.1, \mathrm{MIC}_{\text {estimated }}=50.6,52.7 \mu \mathrm{M}\right.$ for $12 \mathrm{~d}$ and 12a, respectively). Meanwhile, the nitrogen atom of pyrazinecarboxamide function of compounds 12e and 12b are aligned with HBD-1 and HBD-2, respectively $\left(\mathrm{MIC}_{\text {observed }}=51.2\right.$, $58.4, \mathrm{MIC}_{\text {estimated }}=48.0,56.9 \mu \mathrm{M}$ for $12 \mathrm{e}$ and $12 \mathrm{~b}$, respectively) (ESI Table S11†).

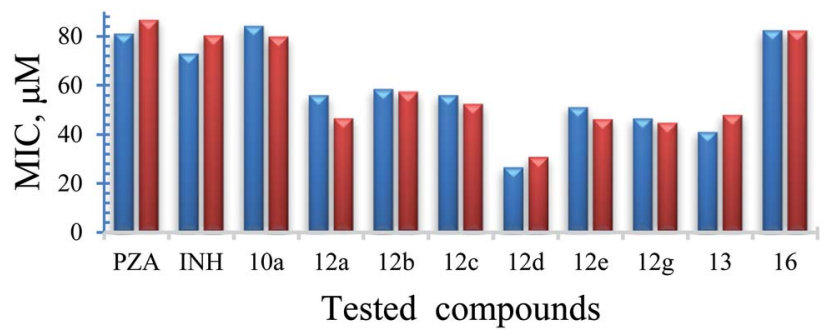

Fig. 4 Observed and estimated activity MIC values for the tested compounds against Mycobacterium marinum according to the BMLRQSAR model.

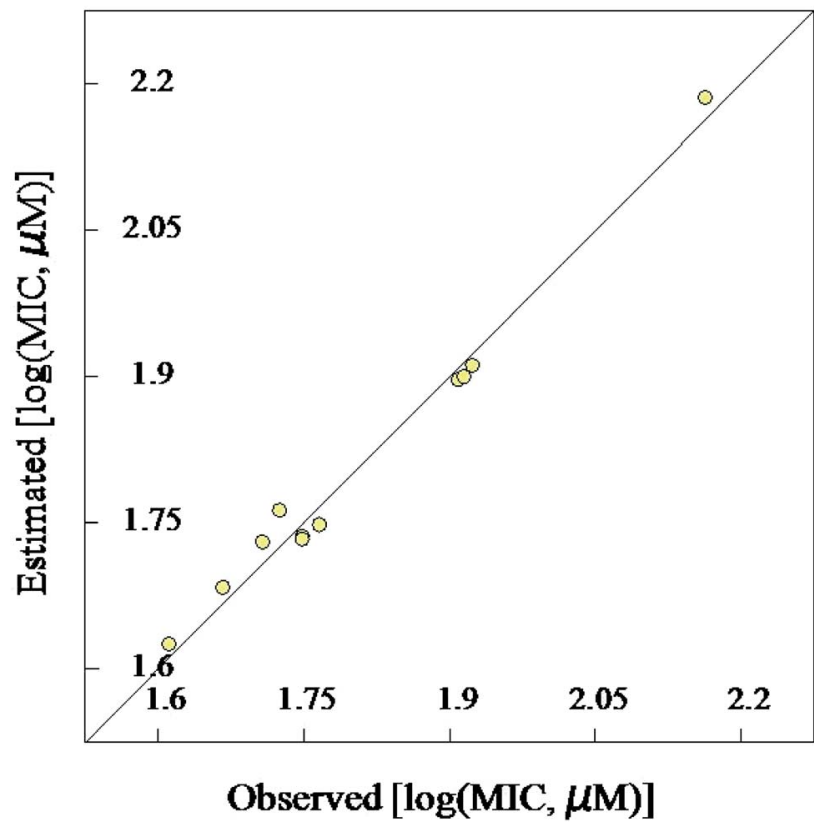

Fig. 5 BMLR-QSAR model plot of correlations representing the observed vs. predicted $\log (\mathrm{MIC}, \mu \mathrm{M})$ values for the tested compounds against Mycobacterium fortuitum.

Mycobacterium tuberculosis. Three chemical features (hydrogen bonding donor, acceptor and a hydrophobic) were observed for the biologically active compounds against $M$. tuberculosis in the 3D-pharmacophoric study utilizing their \% growth inhibition at $30 \mu \mathrm{g} \mathrm{mL}{ }^{-1}$. All the tested conjugates (12ac, 12e, and 12g) show alignment of the isonicotinyl $\mathrm{N}-1$ and amino acid carbonyl with the hydrogen bonding donor and acceptor, respectively while the pyridinyl heterocycle is aligned with the hydrophobic function. Compound $\mathbf{1 3}$ also reveals a similar alignment with a slight difference where the carbonyl of pyrazinoic acid is aligned with the hydrogen bonding donor. Compounds 10a, c, d, e show alignment of the amino acid carbonyl and its alkyl fragment with the hydrogen bonding acceptor and hydrophobic, respectively while the pyrazinamide nitrogen with the hydrogen bonding donor function. Slight division was observed for compounds $\mathbf{1 0 b}, \mathbf{g}$ where the pyrazinyl heterocycle $\mathrm{N}-1$ is aligned with the hydrogen bonding acceptor function. Most of the estimated properties due to the pharmacophoric model preserve the potencies of the tested compounds (ESI Table S12, Fig. S5 and S6†).

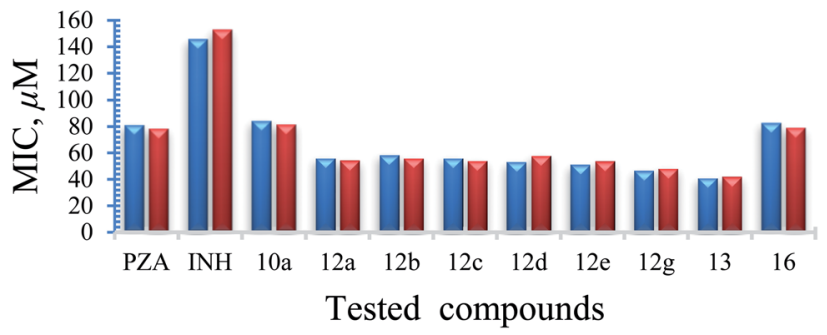

Fig. 6 Observed and estimated activity MIC values for the tested compounds against Mycobacterium fortuitum according to the BMLR-QSAR model. 


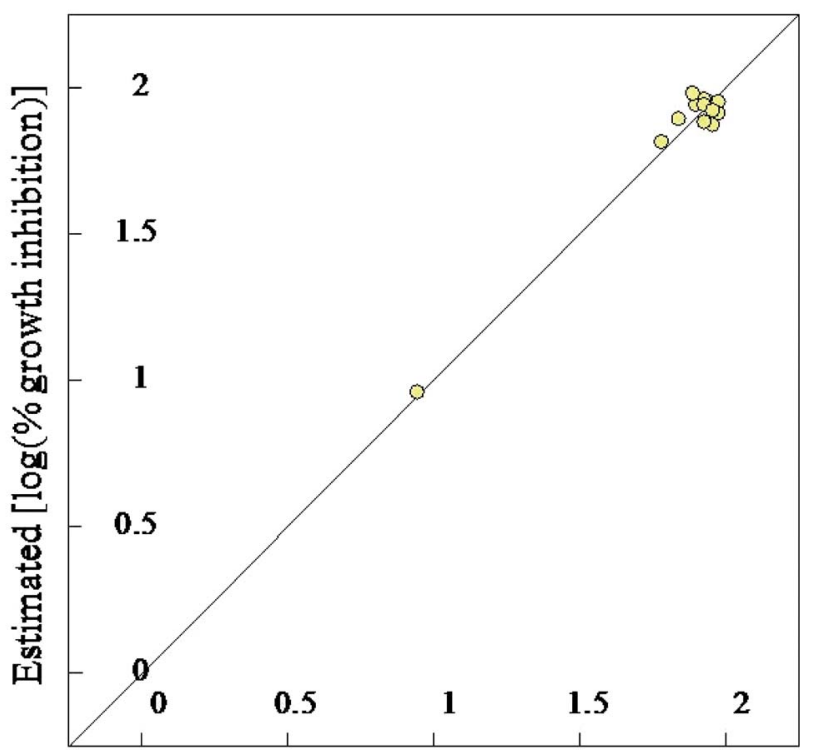

Observed [log(\% growth inhibition)]

Fig. 7 BMLR-QSAR model plot of correlations representing the observed vs. predicted log(\% growth inhibition at $30 \mu \mathrm{g} \mathrm{mL}^{-1}$ ) values for the tested compounds against Mycobacterium tuberculosis.

From all the above 3D-pharmocophoric model observations it is obvious that, alignment of various nitrogen atoms with the pharmacophoric functions, is the main controlling parameter revealing bio-properties. These are common observations between the two techniques utilized in the present computational study (2D-QSAR and 3D-pharmacophore) where, the 2D-QSAR studies reveal important descriptors dealing with nitrogen atoms governing bioproperties (max. e-n attraction for bond $\mathrm{C}-\mathrm{N}$ for the QSAR model of $M$. marinum, max. e-e repulsion for atom N, avg. electroph. react. index for atom $\mathrm{N}$ for the QSAR model of $M$. fortuitum and min. e-e repulsion for bond $\mathrm{H}-\mathrm{N}$ for the QSAR model of $M$. tuberculosis).

\section{ADMET (absorption, distribution, metabolism, excretion and toxicity) studies}

Computed ADMET studies were undertaken by Discovery Studio 2.5 software. From the results obtained it has been noticed that most of the tested compounds show optimal aqueous solubility and good to moderate intestinal absorption. Blood brain barrier penetration (BBB) is ranging from low to very low level. Many of

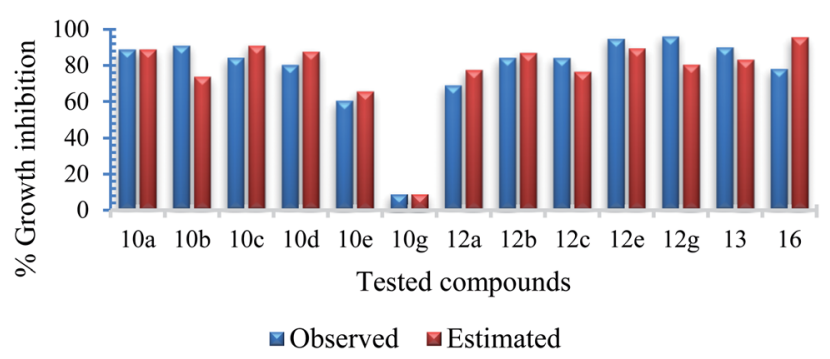

Fig. 8 Observed and estimated activity \% growth inhibition values at $30 \mu \mathrm{g} \mathrm{mL} \mathrm{m}^{-1}$ for the tested compounds against Mycobacterium tuberculosis according to the BMLR-QSAR model.
Table 3 ADMET descriptor values for the tested compounds

\begin{tabular}{llllll}
\hline Entry & Compd & A.S. $^{a}$ & I.A. $^{b}$ & BBB $^{c}$ & PPB $^{d}$ \\
\hline 1 & PZA & 5 & 1 & 3 & 0 \\
2 & INH & 4 & 0 & 3 & 1 \\
3 & 10a & 4 & 0 & 3 & 0 \\
4 & 10b & 4 & 0 & 3 & 0 \\
5 & 10c & 4 & 0 & 3 & 0 \\
6 & 10d & 4 & 0 & 3 & 0 \\
7 & 10e & 4 & 0 & 3 & 2 \\
8 & $\mathbf{1 0 g}$ & 3 & 0 & 3 & 2 \\
9 & $\mathbf{1 2 a}$ & 4 & 1 & 4 & 0 \\
10 & $\mathbf{1 2 b}$ & 4 & 1 & 4 & 0 \\
11 & $\mathbf{1 2 c}$ & 4 & 1 & 4 & 0 \\
12 & $\mathbf{1 2 d}$ & 4 & 1 & 4 & 1 \\
13 & $\mathbf{1 2 e}$ & 4 & 1 & 4 & 2 \\
14 & $\mathbf{1 2 g}$ & 3 & 1 & 4 & 2 \\
15 & $\mathbf{1 3}$ & 4 & 0 & 4 & 2 \\
16 & $\mathbf{1 6}$ & 4 & 0 & 3 & 2
\end{tabular}

${ }^{a}$ A.S. (aqueous solubility) level: 0, 1, 2, 3, 4, 5 and 6 corresponding to extremely low, very low, low; good, optimal, too soluble and unknown, respectively. ${ }^{b}$ I.A. (intestinal absorption) level: $0,1,2$ and 3 corresponding to good, moderate, poor and very poor, respectively. ${ }^{c}$ BBB (blood brain barrier penetration) level: 0, 1,2,3, 4 corresponding to very good, high, medium, low and very low, respectively. ${ }^{d} \mathrm{PPB}$ (plasma protein binding) level: $0,1,2$ corresponding to $<90 \%,>90 \%$ and $>95 \%$, respectively.

the tested compounds show non-hepatotoxicity (Table 3). These computational observations indicate that many of the constructed compounds are good hits to be handled by more sophisticated biological/pharmacological studies for optimizing promising bio-active agents. The predicted ADMET properties are encouraging and we will further study the best conjugates on animal models to generate experimental data. In addition, our synthesized conjugates follow the Lipinski rule of five, which is used to evaluate drug likeness.

\section{Conclusions}

In conclusion, a series of novel hybrid conjugates of pyrazinoic acid, isoniazid was synthesized using optimized benzotriazole, and microwave assisted methodology. The synthesized conjugates showed strikingly high activity against various bacterial and mycobacterial strains relative to the parent drugs. The presence of amino acid in the hybrid conjugates also participates in enhancing the activity. The biological data was supported by different computational techniques (3D-pharmacophore and 2DQSAR). The robust models could be utilized further for developing more potent drug-like molecules. In our future studies, we will explore the possibilities of other linkers as well as dipeptides and tripeptides to unfold the structural activity relationship. In our future study, we will further investigate the molecular mechanism of action by using animal models.

\section{Experimental section}

\section{Chemistry}

General methods. Melting points were determined on a capillary point apparatus equipped with a digital 
thermometer. Reactions were monitored using thin layer chromatography (TLC) on $0.2 \mathrm{~mm}$ silica gel F254 plates (Merck). The chemical structures of final products and intermediates were characterized by nuclear magnetic resonance spectra $\left({ }^{1} \mathrm{H}\right.$ NMR, ${ }^{13} \mathrm{C}$ NMR) and determined on a Bruker NMR spectrometer $(500 \mathrm{MHz}, 125 \mathrm{MHz}) .{ }^{13} \mathrm{C}$ NMR spectra are fully decoupled. Chemical shifts were reported in parts per million (ppm) using a deuterated solvent peak or tetramethylsilane as an internal standard. The chemical structures of final products were confirmed on a high-resolution Biosystems QStar Elite time-offlight electrospray mass spectrometer. HRMS was performed on an Agilent 6210 instrument using time-of-flight mass spectrometry (TOF-MS) with electrospray ionization (ESI). HPLC studies carried out on Agilent 6120 LCMS instrument using Chirobiotic T column.

General procedure: synthesis of pyrazinoic acid-amino acid conjugates $10 \mathrm{a}-\mathrm{g}$. A $50 \mathrm{~mL}$ round bottom flask containing a small stir bar was charged with benzotriazole activated pyrazinoic acid 8 (0.5 g, $2.22 \mathrm{mM})$ and amino acid 9a-g (2.22 $\mathrm{mM})$ dissolved in a mixture acetonitrile and water $(7: 3)$ along with trimethylamine $(3.33 \mathrm{mM})$. The reaction mixture was stirred at room temperature for 3-4 h and TLC monitored the progress of the reaction. After completion of the reaction, the acetonitrile was evaporated under reduced pressure and the residue was treated with $4 \mathrm{~N} \mathrm{HCl}$ solution. The precipitate formed was filtered, washed with water and dried under vacuum to get the desired products $\mathbf{1 0 a}-\mathbf{g}$.

(Pyrazine-2-carbonyl)--leucine (10a). White amorphous, yield (78\%), mp 155-156 ${ }^{\circ} \mathrm{C} ;{ }^{1} \mathrm{H} \mathrm{NMR}\left(500 \mathrm{MHz}, \mathrm{CDCl}_{3}\right) \delta 9.40(\mathrm{~s}, 1 \mathrm{H})$, $8.78(\mathrm{~s}, 1 \mathrm{H}), 8.58(\mathrm{~s}, 1 \mathrm{H}), 8.12(\mathrm{~d}, J=8.4 \mathrm{~Hz}, 1 \mathrm{H}), 4.89-4.54(\mathrm{~m}$, 1H), $1.91-1.76(\mathrm{~m}, 3 \mathrm{H}), 1.01$ (d, $J=4.8 \mathrm{~Hz}, 6 \mathrm{H}) .{ }^{13} \mathrm{C} \mathrm{NMR}(125$ $\left.\mathrm{MHz}, \mathrm{CDCl}_{3}\right) \delta 176.7,163.0,147.3,144.3,144.1,142.9,50.8$, 41.3, 25.0, 22.9, 21.8. HRMS $m / z$ for $\mathrm{C}_{11} \mathrm{H}_{15} \mathrm{~N}_{3} \mathrm{O}_{3}[\mathrm{M}+\mathrm{H}]^{+}$calcd 238.1186. Found: 238.1189.

(Pyrazine-2-carbonyl)-L-valine (10b). White amorphous, yield (88\%), mp 160-162 ${ }^{\circ} \mathrm{C} ;{ }^{1} \mathrm{H}$ NMR (500 MHz, $\left.\mathrm{CDCl}_{3}\right) \delta 9.40(\mathrm{~s}, 1 \mathrm{H})$, $8.78(\mathrm{~s}, 1 \mathrm{H}), 8.59(\mathrm{~s}, 1 \mathrm{H}), 8.26(\mathrm{~d}, J=8.8 \mathrm{~Hz}, 1 \mathrm{H}), 4.80(\mathrm{dd}, J=$ 8.8, $4.5 \mathrm{~Hz}, 1 \mathrm{H}), 2.45-2.37(\mathrm{~m}, 1 \mathrm{H}), 1.07$ (t, $J=6.0 \mathrm{~Hz}, 6 \mathrm{H}) .{ }^{13} \mathrm{C}$ NMR (125 MHz, $\left.\mathrm{CDCl}_{3}\right) \delta$ 175.7, 163.1, 147.3, 147.2, 144.3, 144.2, 144.2, 142.9, 57.2, 31.3, 19.2, 17.7. HRMS $m / z$ for $\mathrm{C}_{10} \mathrm{H}_{13} \mathrm{~N}_{3} \mathrm{O}_{3}[\mathrm{M}$ $+\mathrm{H}]^{+}$calcd 224.1029. Found: 224.1031.

(Pyrazine-2-carbonyl)-L-alloisoleucine (10c). White amorphous, yield (81\%), mp $164-166{ }^{\circ} \mathrm{C} ;{ }^{1} \mathrm{H}$ NMR $\left(500 \mathrm{MHz} \mathrm{CDCl}_{3}\right) \delta 9.40(\mathrm{~s}$, $1 \mathrm{H}), 8.78(\mathrm{~s}, 1 \mathrm{H}), 8.59(\mathrm{~s}, 1 \mathrm{H}), 8.27$ (d, $J=8.7 \mathrm{~Hz}, 1 \mathrm{H}), 4.84$ (dd, $J$ $=8.8,4.6 \mathrm{~Hz}, 1 \mathrm{H}), 2.14-2.08(\mathrm{~m}, 1 \mathrm{H}), 1.66-1.55(\mathrm{~m}, 1 \mathrm{H}), 1.38-$ $1.27(\mathrm{~m}, 1 \mathrm{H}), 1.05(\mathrm{~d}, J=6.8 \mathrm{~Hz}, 3 \mathrm{H}), 0.99(\mathrm{t}, J=7.4 \mathrm{~Hz}, 3 \mathrm{H}) .{ }^{13} \mathrm{C}$ NMR (125 MHz, $\mathrm{CDCl}_{3}$ ) $\delta$ 175.8, 162.9, 147.3, 144.3, 142.9, 56.6, 37.9, 25.1, 15.7, 11.6. HRMS $m / z$ for $\mathrm{C}_{11} \mathrm{H}_{15} \mathrm{~N}_{3} \mathrm{O}_{3}[\mathrm{M}+\mathrm{H}]^{+}$calcd 238.1186. Found: 238.1182.

(Pyrazine-2-carbonyl)-L-methionine (10d). White amorphous, yield (76\%), mp $136-138{ }^{\circ} \mathrm{C} ;{ }^{1} \mathrm{H}$ NMR $\left(500 \mathrm{MHz}, \mathrm{CDCl}_{3}\right) \delta 10.27$ (bs, $1 \mathrm{H}), 9.40(\mathrm{~s}, 1 \mathrm{H}), 8.80(\mathrm{~s}, 1 \mathrm{H}), 8.60(\mathrm{~s}, 1 \mathrm{H}), 8.40(\mathrm{~d}, J=8.0 \mathrm{~Hz}$, $1 \mathrm{H}), 4.99$ (dd, $J=12.6,7.5 \mathrm{~Hz}, 1 \mathrm{H}), 2.64$ (t, $J=7.3 \mathrm{~Hz}, 2 \mathrm{H}), 2.43-$ $2.33(\mathrm{~m}, 1 \mathrm{H}), 2.27-2.16(\mathrm{~m}, 1 \mathrm{H}), 2.12(\mathrm{~s}, 3 \mathrm{H}) .{ }^{13} \mathrm{C} \mathrm{NMR}(125 \mathrm{MHz}$, $\left.\mathrm{CDCl}_{3}\right) \delta 175.4,163.1,147.3,144.2,143.0,51.6,31.5,30.1$, 15.5. HRMS $m / z$ for $\mathrm{C}_{10} \mathrm{H}_{13} \mathrm{~N}_{3} \mathrm{O}_{3} \mathrm{~S}[\mathrm{M}+\mathrm{H}]^{+}$calcd 256.0750. Found: 256.0755 .
(Pyrazine-2-carbonyl)-L-phenylalanine (10e). Yellow amorphous, yield $0.15 \mathrm{~g}$ (98\%), mp $165-166{ }^{\circ} \mathrm{C} ;{ }^{1} \mathrm{H}$ NMR $(500 \mathrm{MHz}$, DMSO- $\left.d_{6}\right) \delta 13.01(\mathrm{bs}, 1 \mathrm{H}), 9.17(\mathrm{~s}, 1 \mathrm{H}), 8.88(\mathrm{~s}, 1 \mathrm{H}), 8.87(\mathrm{~s}, 1 \mathrm{H})$, $8.74(\mathrm{~s}, 1 \mathrm{H}), 7.27(\mathrm{~s}, 4 \mathrm{H}), 7.21-7.16(\mathrm{~m}, 1 \mathrm{H}), 4.99(\mathrm{dd}, J=12.6$, $7.8 \mathrm{~Hz}, 1 \mathrm{H}), 3.30-3.20(\mathrm{~m}, 2 \mathrm{H}) .{ }^{13} \mathrm{C}$ NMR (125 MHz, DMSO- $\left.d_{6}\right)$ $\delta 172.4,162.6,147.9,144.1,143.5,137.5,129.1,128.3,126.5$, 53.5, 36.1. HRMS $m / z$ for $\mathrm{C}_{14} \mathrm{H}_{13} \mathrm{~N}_{3} \mathrm{O}_{3}[\mathrm{M}+\mathrm{H}]^{+}$calcd 272.1029. Found: 272.1032.

(Pyrazine-2-carbonyl)-DL-phenylalanine (10f). Yellow amorphous, yield (94\%), mp 155-157 ${ }^{\circ} \mathrm{C} ;{ }^{1} \mathrm{H}$ NMR (500 MHz, DMSO$\left.d_{6}\right) \delta 9.15(\mathrm{~s}, 1 \mathrm{H}), 8.88(\mathrm{~s}, 1 \mathrm{H}), 8.86(\mathrm{~s}, 1 \mathrm{H}), 8.74(\mathrm{~s}, 1 \mathrm{H}), 7.25(\mathrm{~s}$, $4 \mathrm{H}), 7.23-7.14(\mathrm{~m}, 1 \mathrm{H}), 4.81-4.73(\mathrm{~m}, 1 \mathrm{H}), 3.29-3.18(\mathrm{~m}, 2 \mathrm{H})$. ${ }^{13} \mathrm{C}$ NMR $\left(125 \mathrm{MHz}, \mathrm{DMSO}-d_{6}\right) \delta 172.4,162.7,147.9,144.1$, $143.5,137.5$, 129.1, 128.3, 126.5, 53.5, 36.1. HRMS $\mathrm{m} / \mathrm{z}$ for $\mathrm{C}_{14} \mathrm{H}_{13} \mathrm{~N}_{3} \mathrm{O}_{3}[\mathrm{M}+\mathrm{H}]^{+}$calcd 272.1029. Found: 272.1030.

(Pyrazine-2-carbonyl)-L-tryptophan (10g). Yellow amorphous, yield (93\%), mp 127-129 ${ }^{\circ} \mathrm{C}$; ${ }^{1} \mathrm{H}$ NMR (500 MHz, DMSO- $d_{6}$ ) $\delta 13.01(\mathrm{bs}, 1 \mathrm{H}), 10.85(\mathrm{~s}, 1 \mathrm{H}), 9.17(\mathrm{~s}, 1 \mathrm{H}), 8.88(\mathrm{~s}, 1 \mathrm{H}), 8.72(\mathrm{~d}, J$ $=7.7 \mathrm{~Hz}, 1 \mathrm{H}), 8.70(\mathrm{~s}, 1 \mathrm{H}), 7.52(\mathrm{~d}, J=8.0 \mathrm{~Hz}, 1 \mathrm{H}), 7.32(\mathrm{~d}, J=$ $8.0 \mathrm{~Hz}, 1 \mathrm{H}), 7.16(\mathrm{~s}, 1 \mathrm{H}), 7.04(\mathrm{t}, J=7.4 \mathrm{~Hz}, 1 \mathrm{H}), 6.92(t, J=$ $7.1 \mathrm{~Hz}, 1 \mathrm{H}), 4.82-4.75(\mathrm{~m}, 1 \mathrm{H}), 3.36$ (s, 2H). ${ }^{13} \mathrm{C}$ NMR $(125 \mathrm{MHz}$, DMSO- $\left.d_{6}\right) \delta 172.6,162.4,147.7,143.9,143.3,136.0,127.1,123.6$, 120.9, 118.1, 111.3, 109.4, 52.8, 26.5. HRMS $m / z$ for $\mathrm{C}_{16} \mathrm{H}_{14} \mathrm{~N}_{4} \mathrm{O}_{3}$ $[\mathrm{M}+\mathrm{H}]^{+}$calcd 311.1138. Found: 311.1145.

General procedure: synthesis of pyrazinoic acid-aminoacyl benzotriazolides 11a-g. $1 H$-Benzotriazole $7(4.0 \mathrm{mM})$ was dissolved in anhydrous methylene chloride $(30 \mathrm{~mL})$. Thionyl chloride $(1.2 \mathrm{mM})$ was added and stirred for $30 \mathrm{~min}$. Reduced the reaction mixture temperature to $-15{ }^{\circ} \mathrm{C}$ and then corresponding pyrazinoic acid-amino acid conjugates (10a-g, 1.0 $\mathrm{mM}$ ) was added. The reaction mixture was stirred for $4-5 \mathrm{~h}$ at $-15{ }^{\circ} \mathrm{C}$. Upon completion of the reaction, the reaction mixture was filtered and the filtrate was evaporated under reduced pressure. The residue was treated with $10 \%$ solution of sodium carbonate and the precipitate obtained was filtered, washed with water and dried to yield the desired product 11a-g.

(S)-N-(1-(1H-Benzo[d][1,2,3]triazol-1-yl)-4-methyl-1-oxopentan2-yl)pyrazine-2-carboxamide (11a). White amorphous, yield (88\%), mp 144-146 ${ }^{\circ} \mathrm{C} ;{ }^{1} \mathrm{H}$ NMR $\left(500 \mathrm{MHz}, \mathrm{CDCl}_{3}\right) \delta 9.37(\mathrm{~s}, 1 \mathrm{H})$, $8.78(\mathrm{~s}, 1 \mathrm{H}), 8.59(\mathrm{~s}, 1 \mathrm{H}), 8.46(\mathrm{~d}, J=8.2 \mathrm{~Hz}, 1 \mathrm{H}), 8.23(\mathrm{~d}, J=$ $8.2 \mathrm{~Hz}, 1 \mathrm{H}), 8.12(\mathrm{~d}, J=8.2 \mathrm{~Hz}, 1 \mathrm{H}), 7.64(\mathrm{t}, J=7.8 \mathrm{~Hz}, 1 \mathrm{H}), 7.51$ $(\mathrm{t}, J=7.8 \mathrm{~Hz}, 1 \mathrm{H}), 6.28-6.21(\mathrm{~m}, 1 \mathrm{H}), 2.09-1.84(\mathrm{~m}, 3 \mathrm{H}), 1.12(\mathrm{~d}$, $J=6.6 \mathrm{~Hz}, 3 \mathrm{H}), 0.99$ (d, $J=6.6 \mathrm{~Hz}, 3 \mathrm{H}) .{ }^{13} \mathrm{C} \mathrm{NMR}(125 \mathrm{MHz}$, $\left.\mathrm{CDCl}_{3}\right) \delta 171.6,163.2,147.7,146.1,144.5,143.9,142.8,131.2$, $130.8,126.5,120.4,114.4,51.8,41.8,25.5,23.2,21.4$. HRMS $m / z$ for $\mathrm{C}_{17} \mathrm{H}_{18} \mathrm{~N}_{6} \mathrm{O}_{2}[\mathrm{M}+\mathrm{H}]^{+}$calcd 339.1564. Found: 339.1570.

(S)-N-(1-(1H-Benzo[d][1,2,3]triazol-1-yl)-3-methyl-1-oxobutan-2yl)pyrazine-2-carboxamide (11b). White amorphous, yield (77\%), mp 133-135 ${ }^{\circ} \mathrm{C} ;{ }^{1} \mathrm{H}$ NMR (500 MHz, $\left.\mathrm{CDCl}_{3}\right) \delta 9.41(\mathrm{~s}, 1 \mathrm{H}), 8.80(\mathrm{~s}$, $1 \mathrm{H}), 8.63(\mathrm{~s}, 1 \mathrm{H}), 8.57(\mathrm{~d}, J=8.2 \mathrm{~Hz}, 1 \mathrm{H}), 8.29(\mathrm{~d}, J=8.2 \mathrm{~Hz}, 1 \mathrm{H})$, $8.16(\mathrm{~d}, J=8.2 \mathrm{~Hz}, 1 \mathrm{H}), 7.69(\mathrm{t}, J=7.5 \mathrm{~Hz}, 1 \mathrm{H}), 7.55(\mathrm{t}, J=7.5 \mathrm{~Hz}$, $1 \mathrm{H}), 6.18(\mathrm{dd}, J=8.7,5.2 \mathrm{~Hz}, 1 \mathrm{H}), 2.74-2.64(\mathrm{~m}, 1 \mathrm{H}), 1.19(\mathrm{~d}, J=$ $6.8 \mathrm{~Hz}, 3 \mathrm{H}), 1.10(\mathrm{~d}, J=6.8 \mathrm{~Hz}, 3 \mathrm{H}) .{ }^{13} \mathrm{C} \mathrm{NMR}\left(125 \mathrm{MHz}, \mathrm{CDCl}_{3}\right)$ $\delta 170.9,163.3,147.7,146.1,144.6,144.0,142.8,131.1,130.8$, $126.6,120.5,114.4,57.7,31.9,19.9,17.3$. HRMS $m / z$ for $\mathrm{C}_{16} \mathrm{H}_{16} \mathrm{~N}_{6} \mathrm{O}_{2}[\mathrm{M}+\mathrm{H}]^{+}$calcd 325.1407. Found: 325.1411. 
$N-((2 S, 3 S)-1-(1 H-B e n z o[d][1,2,3]$ triazol-1-yl)-3-methyl-1-oxopentan2-yl)pyrazine-2-carboxamide (11c). White amorphous, yield (69\%), mp 186-188 ${ }^{\circ} \mathrm{C} ;{ }^{1} \mathrm{H}$ NMR (500 MHz, $\left.\mathrm{CDCl}_{3}\right) \delta 9.40(\mathrm{~s}, 1 \mathrm{H}), 8.80(\mathrm{~s}$, $1 \mathrm{H}), 8.62(\mathrm{~s}, 1 \mathrm{H}), 8.56(\mathrm{~d}, J=8.5 \mathrm{~Hz}, 1 \mathrm{H}), 8.29(\mathrm{~d}, J=8.2 \mathrm{~Hz}, 1 \mathrm{H})$, $8.16(\mathrm{~d}, J=8.2 \mathrm{~Hz}, 1 \mathrm{H}), 7.69(\mathrm{t}, J=7.5 \mathrm{~Hz}, 1 \mathrm{H}), 7.55(\mathrm{t}, J=7.5 \mathrm{~Hz}$, $1 \mathrm{H}), 6.18(\mathrm{dd}, J=8.7,5.2 \mathrm{~Hz}, 1 \mathrm{H}), 2.50-2.38(\mathrm{~m}, 1 \mathrm{H}), 1.74-1.64(\mathrm{~m}$, $1 \mathrm{H}), 1.43-1.31(\mathrm{~m}, 1 \mathrm{H}), 1.15(\mathrm{~d}, J=6.8 \mathrm{~Hz}, 3 \mathrm{H}), 0.95(\mathrm{t}, J=7.4 \mathrm{~Hz}$, $3 \mathrm{H}) .{ }^{13} \mathrm{C}$ NMR $\left(125 \mathrm{MHz}, \mathrm{CDCl}_{3}\right) \delta 170.9,163.2,147.7,146.1,144.6$, 143.9, 142.8, 131.1, 130.8, 126.6, 120.5, 114.4, 57.4, 38.4, 24.4, 16.2, 11.3. HRMS $m / z$ for $\mathrm{C}_{17} \mathrm{H}_{18} \mathrm{~N}_{6} \mathrm{O}_{2}[\mathrm{M}+\mathrm{H}]^{+}$calcd 339.1564. Found: 339.1573.

(S)-N-(1-(1H-Benzo[d][1,2,3]triazol-1-yl)-4-(methylthio)-1-oxobutan2-yl)pyrazine-2-carboxamide (11d). White amorphous, yield (74\%), mp 171-173 ${ }^{\circ} \mathrm{C} ;{ }^{1} \mathrm{H}$ NMR (500 MHz, $\left.\mathrm{CDCl}_{3}\right) \delta 9.42(\mathrm{~s}, 1 \mathrm{H}), 8.82(\mathrm{~s}$, $1 \mathrm{H}), 8.69(\mathrm{~d}, J=7.9 \mathrm{~Hz}, 1 \mathrm{H}), 8.64(\mathrm{~s}, 1 \mathrm{H}), 8.29(\mathrm{~d}, J=8.2 \mathrm{~Hz}, 1 \mathrm{H})$, $8.18(\mathrm{~d}, J=8.2 \mathrm{~Hz}, 1 \mathrm{H}), 7.71(\mathrm{t}, J=7.5 \mathrm{~Hz}, 1 \mathrm{H}), 7.57(\mathrm{t}, J=7.5 \mathrm{~Hz}$, $1 \mathrm{H}), 6.34(\mathrm{dd}, J=16.5,45.2 \mathrm{~Hz}, 1 \mathrm{H}), 2.77(\mathrm{t}, J=7.2 \mathrm{~Hz}, 2 \mathrm{H}), 2.69-$ 2.59 (m, 1H), 2.45-2.34 (m, 1H), 2.12 (s, 3H). ${ }^{13} \mathrm{C}$ NMR $(125 \mathrm{MHz}$, $\left.\mathrm{CDCl}_{3}\right) \delta 170.6,163.2,147.8,146.1,142.8,131.2,131.0,126.7,120.5$, 114.4, 52.7, 32.4, 30.3, 15.5. HRMS $m / z$ for $\mathrm{C}_{16} \mathrm{H}_{16} \mathrm{~N}_{6} \mathrm{O}_{2} \mathrm{~S}[\mathrm{M}+\mathrm{H}]^{+}$ calcd 357.1128. Found: 357.1125.

(S)-N-(1-(1H-Benzo[d][1,2,3]triazol-1-yl)-1-oxo-3-phenylpropan2-yl)pyrazine-2-carboxamide (11e). Light yellow amorphous, yield (90\%), mp 180-182 ${ }^{\circ} \mathrm{C} ;{ }^{1} \mathrm{H}$ NMR (500 MHz, DMSO- $\left.d_{6}\right) \delta 9.65(\mathrm{~d}, J$ $=6.4 \mathrm{~Hz}, 1 \mathrm{H}), 9.11(\mathrm{~s}, 1 \mathrm{H}), 8.91(\mathrm{~s}, 1 \mathrm{H}), 8.80(\mathrm{~s}, 1 \mathrm{H}), 8.29(\mathrm{~d}, J=$ $8.2 \mathrm{~Hz}, 1 \mathrm{H}), 8.22(\mathrm{~d}, J=8.2 \mathrm{~Hz}, 1 \mathrm{H}), 7.82(\mathrm{t}, J=7.4 \mathrm{~Hz}, 1 \mathrm{H}), 7.65$ $(\mathrm{t}, J=7.4 \mathrm{~Hz}, 1 \mathrm{H}), 7.36(\mathrm{~d}, J=7.0 \mathrm{~Hz}, 2 \mathrm{H}), 7.25(\mathrm{t}, J=6.8 \mathrm{~Hz}$, $2 \mathrm{H}), 7.21-7.14(\mathrm{~m}, 1 \mathrm{H}), 6.20-6.12(\mathrm{~m}, 1 \mathrm{H}), 3.49(\mathrm{~d}, J=6.3 \mathrm{~Hz}$, $2 \mathrm{H}) .{ }^{13} \mathrm{C}$ NMR $\left(125 \mathrm{MHz}, \mathrm{DMSO}-d_{6}\right) \delta 170.5,163.6,148.1,145.4$, $143.9,143.6,136.8,131.2,130.6,129.1,128.4$, 126.8, 120.3, 113.9, 54.7, 36.1. HRMS $m / z$ for $\mathrm{C}_{20} \mathrm{H}_{16} \mathrm{~N}_{6} \mathrm{O}_{2}[\mathrm{M}+\mathrm{H}]^{+}$calcd 373.1408. Found: 373.1412 .

$N-(1-(1 H-B e n z o[d][1,2,3]$ triazol-1-yl)-1-oxo-3-phenylpropan-2-yl) pyrazine-2-carboxamide (11f). Light yellow amorphous, yield $(87 \%), \operatorname{mp} 172-174{ }^{\circ} \mathrm{C} ;{ }^{1} \mathrm{H}$ NMR (500 MHz, DMSO- $\left.d_{6}\right) \delta 9.66(\mathrm{~d}, J$ $=6.5 \mathrm{~Hz}, 1 \mathrm{H}), 9.12(\mathrm{~s}, 1 \mathrm{H}), 8.92(\mathrm{~s}, 1 \mathrm{H}), 8.81(\mathrm{~s}, 1 \mathrm{H}), 8.29(\mathrm{~d}, J=$ $8.2 \mathrm{~Hz}, 1 \mathrm{H}), 8.23(\mathrm{~d}, J=8.2 \mathrm{~Hz}, 1 \mathrm{H}), 7.82(\mathrm{t}, J=7.4 \mathrm{~Hz}, 1 \mathrm{H}), 7.65$ $(\mathrm{t}, J=7.4 \mathrm{~Hz}, 1 \mathrm{H}), 7.36(\mathrm{~d}, J=7.0 \mathrm{~Hz}, 2 \mathrm{H}), 7.25(\mathrm{t}, J=6.8 \mathrm{~Hz}$, $2 \mathrm{H}), 7.21-7.14(\mathrm{~m}, 1 \mathrm{H}), 6.21-6.13(\mathrm{~m}, 1 \mathrm{H}), 3.50(\mathrm{~d}, J=6.4 \mathrm{~Hz}$, 2H). ${ }^{13} \mathrm{C}$ NMR (125 MHz, DMSO- $\left.d_{6}\right) \delta 170.5,163.6,148.1,145.4$, $143.9,143.6,136.8,131.2$, 130.6, 129.1, 128.4, 126.8, 120.3, 113.9, 54.6, 36.0. HRMS $m / z$ for $\mathrm{C}_{20} \mathrm{H}_{16} \mathrm{~N}_{6} \mathrm{O}_{2}[\mathrm{M}+\mathrm{H}]^{+}$calcd 373.1408. Found: 373.1410 .

(S)-N-(1-(1H-Benzo[d][1,2,3]triazol-1-yl)-3-(1H-indol-3-yl)-1oxopropan-2-yl)pyrazine-2-carboxamide (11g). Light yellow amorphous, yield (86\%), mp $169-171{ }^{\circ} \mathrm{C} ;{ }^{1} \mathrm{H}$ NMR $(500 \mathrm{MHz}$, DMSO- $\left.d_{6}\right) \delta 10.87(\mathrm{~s}, 1 \mathrm{H}), 9.47$ (d, $\left.J=6.8 \mathrm{~Hz}, 1 \mathrm{H}\right), 9.12(\mathrm{~s}$, $1 \mathrm{H}), 8.91(\mathrm{~s}, 1 \mathrm{H}), 8.79(\mathrm{~s}, 1 \mathrm{H}), 8.29(\mathrm{~d}, J=8.2 \mathrm{~Hz}, 1 \mathrm{H}), 8.21(\mathrm{~d}$, $J=8.2 \mathrm{~Hz}, 1 \mathrm{H}), 7.82(\mathrm{t}, J=7.4 \mathrm{~Hz}, 1 \mathrm{H}), 7.69-7.61(\mathrm{~m}, 2 \mathrm{H})$, $7.30(\mathrm{~s}, 1 \mathrm{H}), 7.05(\mathrm{t}, J=7.4 \mathrm{~Hz}, 1 \mathrm{H}), 6.94(\mathrm{~d}, J=7.4 \mathrm{~Hz}, 1 \mathrm{H})$, $7.16(\mathrm{~s}, 1 \mathrm{H}), 7.04(\mathrm{t}, J=7.4 \mathrm{~Hz}, 1 \mathrm{H}), 6.92(t, J=7.1 \mathrm{~Hz}, 1 \mathrm{H})$, $6.20(\mathrm{dd}, J=13.3,6.4 \mathrm{~Hz}, 1 \mathrm{H}), 5.76(\mathrm{~s}, 1 \mathrm{H}), 3.64-3.58(\mathrm{~m}, 2 \mathrm{H})$. ${ }^{13} \mathrm{C}$ NMR $\left(125 \mathrm{MHz}, \mathrm{DMSO}-d_{6}\right) \delta 172.8,162.4,147.7,143.8$, 143.3, 143.6, 136.0, 131.1, 130.5, 127.1, 123.5, 121.0, 120.3, $118.1,113.7,111.3,109.4,52.8,26.5$. HRMS $\mathrm{m} / \mathrm{z}$ for $\mathrm{C}_{22} \mathrm{H}_{17} \mathrm{~N}_{7} \mathrm{O}_{2}[\mathrm{M}+\mathrm{H}]^{+}$calcd 412.1516. Found: 412.1524.
General procedure for the synthesis of pyrazinoic acidisoniazid hybrid conjugates 12a-g. A dried heavy-walled Pyrex tube containing a small stir bar was charged with benzotriazole intermediate 11a-g $(0.7 \mathrm{mM})$ and isoniazid $4(0.7 \mathrm{mM})$ dissolved in THF ( $3 \mathrm{~mL})$ along with trimethylamine $(1.1 \mathrm{mM})$. The reaction mixture was exposed to microwave irradiation $(50 \mathrm{~W})$ at a temperature of $70^{\circ} \mathrm{C}$ for $1 \mathrm{~h}$. Each mixture was allowed to cool through an inbuilt system until the temperature had fallen below $30{ }^{\circ} \mathrm{C}$ ( $\left.c a .10 \mathrm{~min}\right)$. The reaction mixture was quenched with ice cold water and the solid obtained was filtered and washed with $10 \% \mathrm{Na}_{2} \mathrm{CO}_{3}$ and water to give the desired compounds $12 \mathrm{a}-\mathrm{g}$.

(S)-N-(1-(2-Isonicotinoylhydrazineyl)-4-methyl-1-oxopentan-2-yl) pyrazine-2-carboxamide (12a). White amorphous, yield (85\%), mp 160-162 ${ }^{\circ} \mathrm{C} ;{ }^{1} \mathrm{H}$ NMR (500 MHz, DMSO- $\left.d_{6}\right) \delta 10.74(\mathrm{~s}, 1 \mathrm{H})$, $10.39(\mathrm{~s}, 1 \mathrm{H}), 9.22(\mathrm{~s}, 1 \mathrm{H}), 8.91(\mathrm{~s}, 1 \mathrm{H}), 8.82-8.67(\mathrm{~m}, 3 \mathrm{H}), 8.70(\mathrm{~d}, J$ $=8.7 \mathrm{~Hz}, 1 \mathrm{H}), 7.78(\mathrm{~d}, J=4.3 \mathrm{~Hz}, 2 \mathrm{H}), 4.80-4.72(\mathrm{~m}, 1 \mathrm{H}), 1.86-$ $1.64(\mathrm{~m}, 3 \mathrm{H}), 0.96(\mathrm{~d}, J=4.7 \mathrm{~Hz}, 3 \mathrm{H}), 0.94(\mathrm{~d}, J=4.7 \mathrm{~Hz}, 3 \mathrm{H}) .{ }^{13} \mathrm{C}$ NMR (125 MHz, DMSO- $\left.d_{6}\right) \delta$ 170.9, 163.9, 162.6, 150.4, 147.8, 144.2, 143.5, 139.3, 121.3, 50.0, 41.2, 24.3, 22.9, 21.6. HRMS $m / z$ for $\mathrm{C}_{17} \mathrm{H}_{20} \mathrm{~N}_{6} \mathrm{O}_{3}[\mathrm{M}+\mathrm{H}]^{+}$calcd 357.1670. Found: 357.1678.

(S)-N-(1-(2-Isonicotinoylhydrazineyl)-3-methyl-1-oxobutan-2-yl) pyrazine-2-carboxamide (12b). White amorphous, yield (87\%), mp $175-177{ }^{\circ} \mathrm{C} ;{ }^{1} \mathrm{H}$ NMR (500 MHz, DMSO- $\left.d_{6}\right) \delta 10.74(\mathrm{~s}, 1 \mathrm{H})$, $10.44(\mathrm{~s}, 1 \mathrm{H}), 9.23(\mathrm{~s}, 1 \mathrm{H}), 8.92(\mathrm{~s}, 1 \mathrm{H}), 8.82-8.72(\mathrm{~m}, 3 \mathrm{H}), 8.50$ $(\mathrm{d}, J=10.6 \mathrm{~Hz}, 1 \mathrm{H}), 7.77(\mathrm{~d}, J=4.6 \mathrm{~Hz}, 2 \mathrm{H}), 4.59-4.52(\mathrm{~m}, 1 \mathrm{H})$, 2.25-2.15 (m, 1H), 1.04 (d, $J=6.6 \mathrm{~Hz}, 3 \mathrm{H}), 0.98$ (d, $J=6.6 \mathrm{~Hz}$, $3 \mathrm{H}) .{ }^{13} \mathrm{C}$ NMR $\left(125 \mathrm{MHz}, \mathrm{DMSO}-d_{6}\right) \delta 170.1,164.39,162.8,150.9$, 148.5, 144.4, 144.0, 139.7, 121.8, 57.0, 40.5, 40.4, 40.2 , 40.0, 39.8, 39.7, 39.5, 31.7, 19.6, 18.7. HRMS $m / z$ for $\mathrm{C}_{16} \mathrm{H}_{18} \mathrm{~N}_{6} \mathrm{O}_{3}[\mathrm{M}+\mathrm{H}]^{+}$ calcd 343.1513. Found: 343.1524.

$\mathrm{N}-((2 S, 3 S)-1-(2-I s o n i c o t i n o y l h y d r a z i n e y l)-3-m e t h y l-1-o x o p e n t a n-$ 2-yl)pyrazine-2-carboxamide (12c). White amorphous, yield (80\%), mp 168-170 ${ }^{\circ} \mathrm{C} ;{ }^{1} \mathrm{H}$ NMR $\left(500 \mathrm{MHz}, \mathrm{DMSO}-d_{6}\right) \delta 10.75$ (s, $1 \mathrm{H}), 10.46(\mathrm{~s}, 1 \mathrm{H}), 9.23(\mathrm{~s}, 1 \mathrm{H}), 8.92(\mathrm{~s}, 1 \mathrm{H}), 8.82-8.72(\mathrm{~m}, 3 \mathrm{H})$, 8.52 (d, $J=9.2 \mathrm{~Hz}, 1 \mathrm{H}), 7.78(\mathrm{~d}, J=4.0 \mathrm{~Hz}, 2 \mathrm{H}), 4.63-4.53(\mathrm{~m}$, $1 \mathrm{H}), 2.09-1.92(\mathrm{~m}, 1 \mathrm{H}), 1.66-1.50(\mathrm{~m}, 1 \mathrm{H}), 1.30-1.12(\mathrm{~m}, 1 \mathrm{H})$, $1.10-0.85(\mathrm{~m}, 6 \mathrm{H}) .{ }^{13} \mathrm{C}$ NMR $\left(125 \mathrm{MHz}, \mathrm{DMSO}-d_{6}\right) \delta 170.2,164.4$, 162.8, 150.9, 148.5, 144.4, 144.0, 139.8, 121.8, 56.1, 55.1, 38.2, 37.7, 26.2, 25.0, 15.7, 14.9, 12.0, 11.4. HRMS $m / z$ for $\mathrm{C}_{17} \mathrm{H}_{20} \mathrm{~N}_{6} \mathrm{O}_{3}$ $[\mathrm{M}+\mathrm{H}]^{+}$calcd 357.1670. Found: 357.1680.

(S)-N-(1-(2-Isonicotinoylhydrazineyl)-4-(methylthio)-1-oxobutan2-yl)pyrazine-2-carboxamide (12d). White amorphous, yield (78\%), mp $145-147{ }^{\circ} \mathrm{C} ;{ }^{1} \mathrm{H}$ NMR (500 MHz, DMSO- $\left.d_{6}\right) \delta 10.75$ (s, $1 \mathrm{H}), 10.40(\mathrm{~s}, 1 \mathrm{H}), 9.20(\mathrm{~s}, 1 \mathrm{H}), 8.89(\mathrm{~s}, 1 \mathrm{H}), 8.87$ (d, $J=8.3 \mathrm{~Hz}$, $1 \mathrm{H}), 8.80-8.71(\mathrm{~m}, 3 \mathrm{H}), 7.77(\mathrm{~d}, J=4.7 \mathrm{~Hz}, 2 \mathrm{H}), 4.77(\mathrm{dd}, J=14.5$, $7.1 \mathrm{~Hz}, 1 \mathrm{H}), 2.66-2.53(\mathrm{~m}, 2 \mathrm{H}), 2.19-2.11(\mathrm{~m}, 2 \mathrm{H}), 2.07(\mathrm{~s}, 3 \mathrm{H}) .{ }^{13} \mathrm{C}$ NMR (125 MHz, DMSO- $\left.d_{6}\right) \delta 170.1,164.0,162.9,150.4,147.8$, 144.3, 143.4, 139.3, 121.3, 51.0, 31.8, 29.4, 14.6. HRMS $\mathrm{m} / \mathrm{z}$ for $\mathrm{C}_{16} \mathrm{H}_{18} \mathrm{~N}_{6} \mathrm{O}_{3} \mathrm{~S}[\mathrm{M}+\mathrm{H}]^{+}$calcd 375.1234. Found: 375.1233 .

(S)-N-(1-(2-Isonicotinoylhydrazineyl)-1-oxo-3-phenylpropan-2-yl) pyrazine-2-carboxamide (12e). Light yellow amorphous, yield (95\%), mp 177-179 ${ }^{\circ} \mathrm{C} ;{ }^{1} \mathrm{H}$ NMR (500 MHz, DMSO- $\left.d_{6}\right) \delta 10.81(\mathrm{~s}, 1 \mathrm{H})$, $10.51(\mathrm{~s}, 1 \mathrm{H}), 9.12(\mathrm{~s}, 1 \mathrm{H}), 8.87(\mathrm{~s}, 1 \mathrm{H}), 8.83-8.69(\mathrm{~m}, 4 \mathrm{H}), 7.79(\mathrm{~s}, 2 \mathrm{H})$, 7.38-7.14 (m, 5H), 5.01-4.98 (m, 1H), 3.29-3.15 (m, 2H). ${ }^{13} \mathrm{C}$ NMR $\left(125 \mathrm{MHz}, \mathrm{DMSO}-d_{6}\right) \delta 170.0,163.9,162.5,150.4,147.8,144.1,143.4$, 
139.3, 137.3, 129.3, 128.2, 126.5, 121.3, 52.8, 37.5. HRMS $\mathrm{m} / \mathrm{z}$ for $\mathrm{C}_{20} \mathrm{H}_{18} \mathrm{~N}_{6} \mathrm{O}_{3}[\mathrm{M}+\mathrm{H}]^{+}$calcd 391.1513. Found: 391.1510.

$N$-(1-(2-Isonicotinoylhydrazineyl)-1-oxo-3-phenylpropan-2-yl) pyrazine-2-carboxamide (12f). Light yellow amorphous, yield (94\%), mp $143-145{ }^{\circ} \mathrm{C} ;{ }^{1} \mathrm{H}$ NMR (500 MHz, DMSO- $d_{6}$ ) $\delta 10.81(\mathrm{~s}, 1 \mathrm{H}), 10.52(\mathrm{~s}, 1 \mathrm{H}), 9.12(\mathrm{~s}, 1 \mathrm{H}), 8.88(\mathrm{~s}, 1 \mathrm{H}), 8.84-$ $8.69(\mathrm{~m}, 4 \mathrm{H}), 7.79(\mathrm{~s}, 2 \mathrm{H}), 7.38-7.11(\mathrm{~m}, 5 \mathrm{H}), 4.99-4.89(\mathrm{~m}$, $1 \mathrm{H}), 3.29-3.15(\mathrm{~m}, 2 \mathrm{H}) .{ }^{13} \mathrm{C}$ NMR $\left(125 \mathrm{MHz}, \mathrm{DMSO}-d_{6}\right)$ $\delta 170.1,164.0,162.6,150.5,147.8,144.1,143.5,139.3,137.4$, $129.3,128.2,126.5,121.4,52.9,37.5$. HRMS $\mathrm{m} / z$ for $\mathrm{C}_{20} \mathrm{H}_{18} \mathrm{~N}_{6} \mathrm{O}_{3}[\mathrm{M}+\mathrm{H}]^{+}$calcd 391.1513. Found: 391.1508 .

(S)-N-(3-(1H-Indol-3-yl)-1-(2-isonicotinoylhydrazineyl)-1-oxopropan2-yl)pyrazine-2-carboxamide (12g). Light yellow amorphous, yield (78\%), mp 243-245 ${ }^{\circ} \mathrm{C}$; ${ }^{1} \mathrm{H}$ NMR (500 MHz, DMSO- $\left.d_{6}\right) \delta \delta 10.80$ (s, $1 \mathrm{H}), 10.52(\mathrm{~s}, 1 \mathrm{H}), 9.25(\mathrm{~s}, 1 \mathrm{H}), 8.84(\mathrm{~s}, 1 \mathrm{H}), 8.70-8.59(\mathrm{~m}, 3 \mathrm{H}), 7.74-$ 7.60 (m, 6H), 7.35-7.08 (m, 4H), 4.64-4.59 (m, 1H), 3.24-3.17 (m, $2 \mathrm{H}) .{ }^{13} \mathrm{C}$ NMR (125 MHz, DMSO- $\left.d_{6}\right) \delta 170.6,165.4,162.8,150.1$, 148.1, 146.0, 144.0, 144.0, 136.7, 134.0, 127.4, 123.4, 121.9, 120.0, 119.8, 118.6, 112.3, 110.0, 55.8, 27.8. HRMS $m / z$ for $\mathrm{C}_{22} \mathrm{H}_{19} \mathrm{~N}_{7} \mathrm{O}_{3}[\mathrm{M}$ $+\mathrm{H}]^{+}$calcd 430.1622. Found: 430.1638 .

$N^{\prime}$-Isonicotinoylpyrazine-2-carbohydrazide (13). A dried heavy-walled Pyrex tube containing a small stir bar was charged with benzotriazole activated pyrazinoic acid $8(0.7 \mathrm{mM})$ and isoniazid $4(0.7 \mathrm{mM})$ dissolved in THF ( $3 \mathrm{~mL})$ along with trimethylamine (1.1 $\mathrm{mM})$. The reaction mixture was exposed to microwave irradiation $(50 \mathrm{~W})$ at a temperature of $70{ }^{\circ} \mathrm{C}$ for $1 \mathrm{~h}$. The mixture was allowed to cool through an inbuilt system until the temperature had fallen below $30{ }^{\circ} \mathrm{C}$ ( $\mathrm{ca} .10 \mathrm{~min}$ ). Upon completion the reaction mixture was quenched with ice cold water and the solid obtained was filtered and washed with $10 \% \mathrm{Na}_{2} \mathrm{CO}_{3}$ and water to give the desired compound. White amorphous, yield (88\%), mp 208$210{ }^{\circ} \mathrm{C}^{.17}{ }^{1} \mathrm{H}$ NMR (500 MHz, DMSO- $\left.d_{6}\right) \delta 10.96$ (bs, $1 \mathrm{H}$ ), 10.91 (s, $1 \mathrm{H}), 9.22(\mathrm{~s}, 1 \mathrm{H}), 8.94(\mathrm{~s}, 1 \mathrm{H}), 8.82-8.77(\mathrm{~m}, 3 \mathrm{H}), 7.82(\mathrm{~d}, J=4.7 \mathrm{~Hz}$, $2 \mathrm{H}) .{ }^{13} \mathrm{C}$ NMR (125 MHz, DMSO- $\left.d_{6}\right) \delta 164.0,162.3,150.5,148.1$, 144.1, 143.8, 143.7, 139.4, 121.3. HRMS $m / z$ for $\mathrm{C}_{11} \mathrm{H}_{9} \mathrm{~N}_{5} \mathrm{O}_{2}[\mathrm{M}+\mathrm{H}]^{+}$ calcd 244.0829. Found: 244.0831.

$\boldsymbol{N}^{\prime}$-Isonicotinoylisonicotinohydrazide (16). A dried heavywalled Pyrex tube containing a small stir bar was charged with benzotriazole activated isonicitinic acid $15(0.7 \mathrm{mM})$ and isoniazid $4(0.7 \mathrm{mM})$ dissolved in THF ( $3 \mathrm{~mL}$ ) along with trimethylamine $(1.1 \mathrm{mM})$. The reaction mixture was exposed to microwave irradiation $(50 \mathrm{~W})$ at a temperature of $70^{\circ} \mathrm{C}$ for $1 \mathrm{~h}$. The mixture was allowed to cool through an inbuilt system until the temperature had fallen below $30^{\circ} \mathrm{C}(\mathrm{ca} .10 \mathrm{~min})$. Upon completion, the reaction mixture was quenched with ice-cold water and the solid obtained was filtered, washed with $10 \% \mathrm{Na}_{2} \mathrm{CO}_{3}$ and water to give the desired compound 16. White amorphous, yield (91\%), mp 212-214 ${ }^{\circ} \mathrm{C}^{\mathbf{1 8 - 2 0}}{ }^{1} \mathrm{H}$ NMR (500 MHz, DMSO- $d_{6}$ ) $\delta 10.95$ (bs, 2H), $8.80(\mathrm{~d}, J=4.6 \mathrm{~Hz}, 2 \mathrm{H}), 7.82(\mathrm{~d}, J=4.6 \mathrm{~Hz}, 2 \mathrm{H}) .{ }^{13} \mathrm{C} \mathrm{NMR}(125$ MHz, DMSO- $\left.d_{6}\right) \delta 164.3,150.5,139.3,121.3$. HRMS $\mathrm{m} / z$ for $\mathrm{C}_{12} \mathrm{H}_{10} \mathrm{~N}_{4} \mathrm{O}_{2}[\mathrm{M}+\mathrm{H}]^{+}$calcd 243.0877. Found: 243.0886.

\section{Biological studies}

Aerobic antibacterial studies. Antibacterial properties were investigated for the synthesized compounds against a variety of Gram-positive (Staphylococcus aureus, Enterococcus faecalis) and
Gram-negative (Klebsiella pneumonia, Proteus vulgaris, Pseudomonas aeruginosa) clinical isolate bacteria utilizing the standard technique. ${ }^{21}$

Antimycobacterial studies. Antimycobacterial properties of the synthesized compounds and standards were screened against clinical isolate tuberculous (Mycobacterium bovis) and nontuberculous (Mycobacterium marinum, Mycobacterium fortuitum) strains using the standard technique $\mathrm{e}^{\mathbf{2 1 , 2 2}}$ and against Mycobacterium tuberculosis by the following described method. Highly virulent $M$. tuberculosis Erdman strain expressing luciferase (MtbLux Erdman) was grown in 7H9 Middlebrook media supplemented with oleic acid, dextrose, albumin, catalase (OADC) and $0.05 \%$ tween 80 at $37^{\circ} \mathrm{C}$. $\mathrm{PH}$ of the culture media was maintained at neutral $\mathrm{pH}(\mathrm{pH}=7.0)$. All the antibiotics were dissolved in $100 \%$ DMSO at a final concentration of $10 \mathrm{mg} \mathrm{mL}^{-1} 10^{6}$ bacteria per $\mathrm{mL}$ were incubated with increasing concentration of antibiotics for 7 days in a round bottom 96 well plate without shaking in a final volume of $300 \mu \mathrm{l}$. Bacterial growth was determined by measuring the luciferase expression (expressed in counts) in a PerkinElmer IVIS-spectrum imaging system kept at the BSL-3 facility of Albany Medical College, Albany, NY. Antibiotics concentrations manifesting $>85 \%$ growth inhibition as measured by a decline in luciferase counts was considered as effective concentration for antimycobacterial activity.

Antiproliferative properties. Antiproliferative properties of the synthesized compounds were tested against RPE1 (normal human immortalized retinal epithelial) cell line at $100 \mu \mathrm{M}$ to determine the toxicity/selectivity towards normal cell by the standard MTT technique. ${ }^{23}$

\section{Computational studies}

2D-QSAR modelling. 2D-QSAR modeling was conducted by the standard technique utilizing CODESSA-Pro software. ${ }^{24}$

3D-pharmacophore modeling. 3D-pharmacophore modeling was undertaken by the standard technique utilizing Discovery Studio 2.5 software. $^{26}$

\section{ADMET studies}

Computed ADMET studies were conducted by the standard technique utilizing Discovery Studio 2.5 software. ${ }^{23}$

\section{Conflicts of interest}

The authors have declared no conflict of interest.

\section{Acknowledgements}

We thank the Center for Undergraduate Research and Scholarship (CURS), Translational Research Program (TRP), and Scholarly Activity Award at Augusta University for financial support.

\section{Notes and references}

1 World Health Organization (WHO), The world health report: 2018 - Monitoring Health for the SDGs, http:/www.who.int/ gho/publications/world_health_statistics/2018/en/. 
2 R. Laxminarayan, A. Duse, C. Wattal, A. K. M. Zaidi, H. F. L. Wertheim, N. Sumpradit, E. Vlieghe, G. L. Hara, I. M. Gould, H. Goossens, C. Greko, A. D. So, M. Bigdeli, G. Tomson, W. Woodhouse, E. Ombaka, A. Q. Peralta, F. N. Qamar, F. Mir, S. Kariuki, Z. A. Bhutta, A. Coates, R. Bergstrom, G. D. Wright, E. D. Brown and O. Cars, Antibiotic resistance-the need for global solutions, Lancet Infect. Dis., 2013, 13, 1057-1098.

3 A. S. Fauci, N. A. Touchette and G. K. Folkers, Emerging infectious diseases: a 10-Year perspective from the national institute of allergy and infectious diseases, Emerging Infect. Dis., 2005, 11, 519-525.

4 B. E. Malmvall, S. Mölstad, J. Darelid, A. Hiselius, L. Larsson, J. Swanberg and P. E. Åbom, Reduction of antibiotics sales and sustained low incidence of bacterial resistance: report on a broad approach during 10 years to implement evidence-based indications for antibiotic prescribing in Jönköping county, Sweden, Qual. Manag. Health Care, 2007, 16, 60-67.

5 World Health Organization, Global Tuberculosis Report, 2017. 6 R. Mirnejad, A. Asadi, S. Khoshnood, H. Mirzaei, M. Heidary, L. Fattorini, A. Ghodousi and D. Darban-Sarokh, Clofazimine: A useful antibiotic for drug-resistant tuberculosis, Biomed. Pharmacother., 2018, 105, 1353-1359.

7 D. Jeon, WHO treatment guidelines for drug-resistant tuberculosis, 2016 update: applicability in South Korea, Tuberc. Respir. Dis., 2017, 80, 336-343.

8 E. Rallis and E. Koumantaki-Mathioudaki, Treatment of Mycobacterium marinum cutaneous infections, Expert Opin. Pharmacother., 2007, 8, 2965-2978.

9 R. Rennert, I. Neundorf and A. G. Beck-Sickinger, Nucleic acid and peptide aptamers, in Methods in Molecular Biology, Humana, New York, NY, USA, 2009, ch. 22, vol. 535, pp. 389-403.

10 K. P. Rakesh, M. H. Marichannegowda, S. Srivastava, X. Chen, S. Long, C. S. Karthik, P. Mallu and H.-L. Qin, Combating a master manipulator: Staphylococcus aureus immunomodulatory molecules as targets for combinatorial drug discovery, ACS Comb. Sci., 2018, 20, 681-693.

11 K. P. Rakesh, H. K. Vivek, H. M. Manukumar, C. S. Shantharam, S. N. A. Bukhari, H.-L. Qin and M. B. Sridhara, Promising bactericidal approach of dihydrazone analogues against bio-film forming Gramnegative bacteria and molecular mechanistic studies, $R S C$ $A d v .$, 2018, 8, 5473-5483.

12 L. Ravindar, S. N. A. Bukhari, K. P. Rakesh, H. M. Manukumar, H. K. Vivek, N. Mallesha, Z.-Z. Xie and H.-L. Qin, Aryl fluorosulfate analogues as potent antimicrobial agents: SAR, cytotoxicity and docking studies, Bioorg. Chem., 2018, 81, 107-118.

13 G.-F. Zha, S.-M. Wang, K. P. Rakesh, S. N. A. Bukhari, H. M. Manukumar, H. K. Vivek, N. Mallesha and H.-L. Qin, Discovery of novel arylethenesulfonyl fluorides as potential candidates against methicillin-resistant of Staphylococcus aureus (MRSA) for overcoming multidrug resistance of bacterial infections, Eur. J. Med. Chem., 2019, 162, 364-377.
14 S. S. Panda, O. S. Detistov, A. S. Girgis, P. P. Mohapatra, A. Samir and A. R. Katritzky, Synthesis and molecular modeling of antimicrobial active fluoroquinolone-pyrazine conjugates with amino acid linkers, Bioorg. Med. Chem. Lett., 2016, 26, 2198-2205.

15 D. U. Ganihigama, S. Sureram, S. Sangher, P. Hongmanee, T. Aree, C. Mahidol, S. Ruchirawat and P. Kittakoop, Antimycobacterial activity of natural products and synthetic agents: Pyrrolodiquinolines and vermelhotin as anti-tubercular leads against clinical multidrug resistant isolates of Mycobacterium tuberculosis, Eur. J. Med. Chem., 2015, 89, 1-12.

16 S. S. Panda, A. M. Asiri, M. Elagawany, D. D. Buchanan, B. Torkian, K. Bathala, S. J. Thomas, J. E. Capito, M. N. Arshad and A. N. Al-Romaizan, Efficient synthesis of pyrazinoic acid hybrid conjugates, SynOpen, 2017, 1, 50-58.

17 P. B. Miniyar and A. R. Bhat, Pyrazinoic acid hydrazide derivatives: synthesis and antimycobacterial activities, Indian J. Heterocycl. Chem., 1999, 9, 155-156.

18 J. Quiroga, J. Portilla, R. Abonia, B. Insuasty, M. Nogueras and J. Cobo, Synthesis of novel 5-amino-1-aroylpyrazoles, Tetrahedron Lett., 2008, 49, 5943-5945.

19 S. A. Ali, H. A. Mohamed and R. M. Ramadan, Novel chromium and molybdenum complexes of a dimerized isonicotinic acid hydrazide, J. Coord. Chem., 2006, 59, 467473.

20 K. Mogilaiah, M. Prashanthi and R. G. Randheer, An efficient oxidation of acid hydrazides to N,N'-diacylhydrazines using copper(II) acetate in solvent-free conditions under microwave irradiation, Synth. Commun., 2003, 33, 37413745.

21 Clinical and Laboratory Standards Institute (Formerly NCCLS), Methods for Dilution Antimicrobial Susceptibility Tests for Bacteria Grow Aerobically, Approved Standard M7A4, Clinical and Laboratory Standards Institute, Wayne, Pennsylvania, USA, 2009.

22 NCCLS, Susceptibility testing of mycobacteria, nocardia and other aerobic actinomycetes, Tentative standard M24-T2, NCCLS, Wayne, PA, USA, 2nd edn, 2000.

23 N. S. M. Ismail, R. F. George, R. A. T. Serya, F. N. Baselious, M. El-Manawaty, E. M. Shalaby and A. S. Girgis, Rational design, synthesis and 2D-QSAR studies of antiproliferative tropane-based compounds, RSC Adv., 2016, 6, 101911101923.

24 A. M. Srour, S. S. Panda, A. M. M. Salman, M. A. ElManawaty, R. F. George, E. M. Shalaby, A. N. Fitch, N. G. Fawzy and A. S. Girgis, Synthesis and molecular modeling studies of bronchodilatory active indole-pyridine conjugates, Future Med. Chem., 2018, 10, 1787-1804.

25 A. R. Katritzky, R. Petrukhin, I. Petrukhina, A. Lomaka, D. B. Tatham and M. Karelson, CODESSA-Pro software manual, 2005, pp. 72, 73, 75.

26 E. A. Soliman, S. S. Panda, M. N. Aziz, E. M. Shalaby, N. Mishriky, F. M. Asaad and A. S. Girgis, Synthesis, molecular modeling studies and bronchodilation properties of nicotinonitrile containing-compounds, Eur. J. Med. Chem., 2017, 138, 920-931. 